STARPDISCIPLINĀRIE PÉTİUMI MEDICĪNAS KOLEDŽĀS

Tēžu krājums

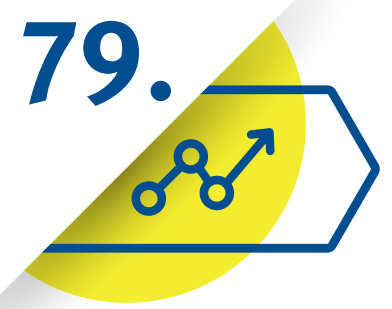

Latvijas Universitātes starptautiskā zinātniskā konference 
LATVIJAS UNIVERSITĀTES 79. STARPTAUTISKĀS ZINĀTNISKĀS KONFERENCES SEKCIJA

\section{STARPDISCIPLINĀRIE PĒTĪJUMI MEDICĪNAS KOLEDŽĀS}

TĚŽU KRĀJUMS 
Latvijas Universitātes 79. starptautiskā zinātniskā konference "Starpdisciplinārie pètījumi medicīnas koledžās”. Tēžu krājums. Rīga: Latvijas Universitāte, 2021.

55 lpp.

Latvijas Universitātes 79. starptautiskās zinātniskās konferences "Starpdisciplinārie pētījumi medicīnas koledžās" tēzes raksturo medicīnas koledžās veikto pētījumu daudzpusību, pētniecības kvalitāti un arī lietišķumu, kas šogad izcel̦as ar raksturvārdiem "drošiba" un "atbildība". Konferencē prezentēto un diskutēto jautājumu loks ievērojami pārsniedz veselības aprūpē apskatīto jautājumu loku un veicinās studentus, pētniekus un sociālos partnerus aktīvāk sadarboties ne tikai studiju kvalitātes uzlabošanā, bet arī pētniecībā.

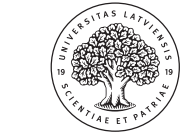

LATVIJAS

UNIVERSITĀTE
LATVIJAS UNIVERSITĀTES RīGAS MEDICINNAS KOLEDŽA
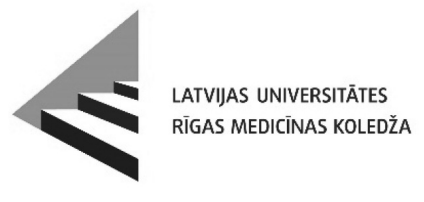

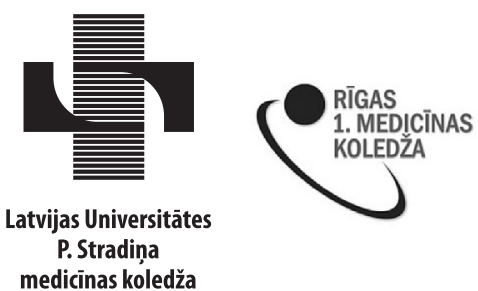

Konferences organizācijas komiteja:

Iveta Strode, Aksels Roshofs, Inta Mik̦ele, Valdis Seglin,š

Atbildīgais redaktors prof. Valdis Segliņš

Sagatavots LU Akadēmiskajā apgādā

Maketētāja: Andra Liepiņa

(C) Latvijas Universitāte, 2021

ISBN 978-9934-18-668-4 (PDF)

https://doi.org/10.22364/luszk.79.spmk.tk 


\section{PRIEKŠVĀRDS}

"Starpdisciplinārie pētījumi medicīnas koledžās" Latvijas Universitātes 79. starptautiskās zinātniskās konferences ietvaros jau kuru gadu apliecina savu varēšanu pētijumos un koledžu spēju stāties blakus pētnieciskiem darbiem universitāšu pamatstudijās sasniegtajam. Lai arī šis gads studijām un pētniecībai nav bijis vienkāršs, un tāds nebūs arī nākamais, pētījumi ir veikti, un nav pārsteigums, ka daudzi no tiem ir pievērsti jautājumiem, kas raksturojami ar atslēgas vārdiem "drošība" un "atbildiba".

Konference, lai arī šogad notiek attālināti tiešsaistē, ir gadskārtējs uzskatāms apliecinājums medicīnas koledžu sniegto teorētisko zināšanu pamatīgumam un spējām tās lietot, uzsākot pētniecības darbu un nereti arī patstāvīgi izstrādājot datu ievākšanas formas, apgūstot jaunas datu apstrādes metodikas vai kritiski izvērtējot citu pētnieku iepriekšējos gados paveikto. Izcel̦ams, ka konferencē piedalās ne tikai P. Stradina medicinas koledža, Rīgas Medicinnas koledža, un Rìgas 1. medicīnas koledža, bet arī Sarkanā Krusta koledža, Rīgas Stradiṇa universitāte un Latvijas Universitātes Medicīnas fakultāte, bet nākotnē sagaidāma aizvien plašāka arī partneru - klīniku un medicīnas centru - iesaiste, tas l̦autu pètỉjumiem kḷūt pamatotākiem, saturiski bagātākiem, un arī autori tad varētu nonākt pie pārliecinošākiem pārbaudāmiem secinājumiem.

Šogad konferencē tiek prezentēti 26 mutiski ziņojumi, kas aptver visai plašu pētniecỉbas virzienu loku, un katrs no tiem ir atškirīigs ar savu spēka pielikšanas punktu, kā arī satur daudz rekomendāciju un ierosmi turpmāko pētỉjumu attīstībai. Jau patlaban vairāki no konferencē prezentētajiem pētijumiem ir ìpaši veiksmīgi, un, tos turpinot, ir pamats sagaidīt pētijumu rezultātu publicēšanu zinātniskos žurnālos. Daudzi konferences ziņojumi apskata vairāk lietišķas ievirzes pētijumus, tādēl tie ir īpaši nozīmīgi ar iespēju nepastarpināti ieviest jauninājumus praksē. Konferences ziṇojumi ir paredzēti diskusijām, jaunām idejām veikto pētījumu metodikas un realizācijas pilnveidē, detalizācijai un vietām arī zinātniskā pamatojuma izvērstākai analīzei. Tādējādi ziņojumi ir aicinājums studentiem, pētniekiem un sociālajiem partneriem pievērsties plašākam pētijumu lokam un saskatìt jaunas pētniecỉbas jomas arī blakus augstvērtīgām studijām veselības aprūpē.

"Starpdisciplinārie pētījumi medicinas koledžās" visai skaidri apliecina, ka Latvijas Universitātē koledžas ir ne tikai augstvērtīgu studiju centri ar plašu studiju un tālākizglìīibas iespēju piedāvājumu, bet tajās tiek veikti arī pētijumi, par kuriem informācija plašākai pētnieku sabiedrībai nereti ir visai ierobežota. Tādējādi katra šāda gadskārtējā konference kḷusst par vietu, kur iespējams ziṇot par savu pētijumu rezultātiem un dalīties pieredzē daudziem, kas darbojas šai jomā.

Konference nebūtu bijusi iespējama, ja tai veltīto pētījumu izstrādi, papildināšanu un vērtēšanu medicīnas koledžās nevadītu talantīgi pasniedzēji un pieredzējuši 
pētnieki, kas ar savu darbu var pamatoti lepoties. Tomēr konferences saturisko kodolu ar saviem pētijumiem veido paši studenti, kas ir spējuši nereti ḷoti šaurā jomā iegūt datus un sekmīgi tos interpretēt starpdisciplinārā zināšanu telpā.

Profesors Dr. geol. Valdis Segliņ̌

2021. gada 22. aprilī 


\section{SATURS}

PRIEKŠVĀRDS

Jelena Urbēna, Maira Lāce, Leila Korejeva, Olga Rozentāle

PACIENTU DROŠİBAS REALIZĀCIJA MEDICINNAS KOLEDŽAS

STUDIJU PROCESĀ KLIINISKAJĀ PRAKSĒ

Rolands Brencāns, Alevtīna Leice

TIESU MEDICINNAS EKSPERTİZES UN LABORATORISKĀ

DIAGNOSTIKA

Germans Ševčenko, Jolanta Pupure

KLASISKĀS KĀJU MASĀŽAS PIELIETOJUMS BALETDEJOTĀJĀM

SKELETA MUSKUL̦U TRAUMU PROFILAKSEI

Inga Kaulina, Olga Rozentāle

ATBILDĪGA ANTIBAKTERIĀLO LĪDZEKL̦U LIETOŠANA

SABIEDRĪBĀ

Signe Ašuka, Rita Geske

VESELİBAS UN APRŪPES PROBLĒMAS BËRNIEM AR

MARFĀNA SINDROMU

Rūta Melbārde-Vāvere, Jellena Urbēna, Ilze Briža

MIKROFLORAS IZVËRTĖJUMS UZ ROKĀM AR GREDZENIEM

Kristiāna Laila Lazdiṇa, Elvīra Lavrinoviča

DEKORATIVĀS KOSMĒTIKAS OTU MAZGĀŠANAS UN

DEZINFEKCIJAS LIIDZEKL̦U EFEKTIVITĀTE

Laura Serafimoviča, Mārīte Saulìte

HOSPITĀLO INFEKCIJU RISKI PODOLOGA PRAKSEE

Margarita Blate, Elvīra Lavrinoviča

DAŽĀDU DEZINFEKCIJAS LİDZEKL̦U EFEKTIVITĀTE ROKU

DEZINFEKCIJAI

Mārtinšs Vesperis

VECMĀŠU DARBĪBAS ASPEKTI 19. GADSIMTĀ

Valda Ametere, Nadežda Bogdanova, Inta Mikele, Inga Priede

MALNUTRITCIJAS IETEKME UZ TRAUMATOLOGIJAS UN

ORTOPËDIJAS PACIENTIEM STACIONĀRĀ

Kitija Bērziṇa, Ruta Kidika, Kārlis Mačāns

SAREŽGTIJUMI RECEPŠU MEDIKAMENTU IZSNIEGŠANĀ

ATVËRTA TIPA APTIEKĀS 
Amanda Medusone, Ineta Robina

VECMĀTES ATBALSTS UN IZGLITTOŠANAS VEIDI

NEDZIRDĪGĀM GRŪTNIECËM UN DZEMDËTĀJĀM

Liene Štikova, Alīna Krivina

DZİVES KVALITĀTES PAŠNOVĒRTËJUMS PACIENTIEM

AR OSTEOARTRITTU

Signe Barinska, Ineta Robina

BIEŽĀKIE ELPCELU CAURLAIDĪBAS NODROŠINĀŠANAS

VEIDI NMPD VIDŹEMES REG̣IONĀ 2019. GADĀ

Eva Briede, Santa Mikele

HALLUX VALGUS PROFILAKSE UN POSTOPERATIVĀ APRŪPE

Aina Sisojeva, Daiga Bērtinna, Maira Vỉksna

MEDIKAMENTOZĀ APRŪPE TIEŠAJĀ PĒCOPERĀCIJAS

PERIODĀ PËC CEL̨A LOCĪTAVAS ENDOPROTEZĚŠANAS

Paula Rosleviča, Renārs Erts, Evija Levenšteina

LIPIDOGRAMMAS RĀDĪTĀJI KARDIOVASKULĀRIEM

PACIENTIEM AR TRAUKSMI, STRESU UN DEPRESIJU

Ksenija Murāne, Renārs Erts, Sandra Seimane

KOGNITIVO TRAUCËJUMU IZVËRTËJUMS PACIENTIEM

AR KARDIOVASKULĀRĀM SLIMĪBĀM

Linda Alondere, Inga Veidemane

AUTONOMIJAS PRINCIPS K̦IRURG̣ISKĀS APRŪPES MĀSAS PRAKSĒ .......

Samanta Bērziña, Jelena Kuzn,ecova

MĀSU UN MEDICĨNAS ASISTENTU IZPRATNE PAR

ERGONOMIKU, TĀS PAMATPRINCIPIEM UN TO PIELIETOJUMU

DARBA VIDË

Montija Bičevska, Sarmìte Villere

ĀRSTA PALİGU MOTIVĀCIJA DARBAM NEATLIEKAMĀS

MEDICİNISKĀS PALĪDZİBAS DIENESTĀ

Inga Rūža, Lìga Priede

DARBA VIDES RISKA FAKTORI SOCIĀLĀS APRŪPES UN

SOCIĀLĀS REHABILITĀCIJAS INSTITŪCIJĀ

Zane Imūne, Kristīne Vítoliña

KLAUSİ̌̌ANĀS PRASME KĀ KOMUNIKĀCIJU IETEKMĒJOŠS

FAKTORS SOCIĀLĀ REHABILITËTĀJA DARBĀ

Kristīne Vitolina, Ina Viksnin,a, Ina Ozola, Lìga Priede

STUDIJU PROCESS KĀ PROFESIONĀLĀS IDENTITĀTES

VEICINĀTĀJS SOCIĀLĀ DARBA SPECIĀLISTIEM 


\title{
PACIENTU DROŠĪBAS REALIZĀCIJA MEDICĪNAS KOLEDŽAS STUDIJU PROCESĀ KLĪNISKAJĀ PRAKSĒ
}

\author{
Jeḷena Urbēna1, Maira Lāce ${ }^{1,2}$, Leila Korejeva ${ }^{1,3}$, Olga Rozentāle $^{1,2}$ \\ ${ }^{1}$ Latvijas Universitātes P. Stradiña medicīnas koledža, Jūrmala, Latvija \\ 2 VSIA "Paula Stradiṇa klīniskā universitātes slimnīca", Rīga, Latvija \\ ${ }^{3}$ SIA "Jūrmalas slimnīca", Jūrmala, Latvija
}

Ievads. Pieaugot procesu intensitātei un palielinoties izmantojamo tehnologiju un medikamentu apjomam, pieaug arī risks nodarīt pacientam kaitējumu. Potenciālais vai esošais kaitējums pacientam ir gan ètiska rakstura problēma, gan sekojoši arī ekonomiska rakstura zaudējumi individuālā, veselības aprūpes sistēmas un valstiskā līmenī. Pacientu drošỉba ir kvalitatīvas veselības aprūpes sistēmas pamats.

Darba mērḳis. Raksturot medicīnas koledžas studentu klīniskajā praksē novērotos pacientu drošỉbas aspektus.

Materiāli un metodes. Latvijas Universitātes P. Stradiṇa medicīnas koledžā studiju kursā "Praktiskās darba iemaṇas pacientu aprūpē" studiju procesa ietvaros 40 ( $n=40$, kas atbilst 100\%) māszinību studiju programmas 2. kursa studentiem sistemātiski tika veikta anonīma anketēšana ar nolūku - uzlabot studentu klīnisko praksi un studiju procesu.

Pētījumā tika veikta kvantitatīva izlases datu analīze par pacientu drošības realizāciju 2019./2020. studiju gada studentu klīniskās prakses laikā. Izmantojamo datu izvēle (kopā 14 jautājumu) pamatota starptautiskajos pacientu drošības mērķos, tika ietverti jautājumi par drošu pacienta identifikāciju, medikamentozo drošību un pacientu medikamentozo aprūpi, starppersonu komunikāciju, biologíiskajiem riskiem un biologisko drošỉbu.

Respondenti sniedza atbildes par prakses norisi, balstoties gan novērojumos, gan pašu veiktajās darbībās. Pētījuma periods 01.03.2020.-01.05.2020. Anketēšana tika veikta, izmantojot Google forms dokumentu vietni. Datu apkopošanai izmantota Microsoft Excel datorprogramma.

Rezultāti. Pacientu identifikācijas gadījumos 24 respondenti (60\%) izmantoja vai novēroja nekorektu pacientu identifikācijas metodi.

Vadlīniju, drošības instrukciju, aprīkojuma un medikamentu drošas izmantošanas dokumentācijas pieejamība ir ierobežota. Par joprojām nepietiekamu vai neesošu informatīvā materiāla pieejamību norāda 16 (40\%) respondentu.

Kā apliecina 14 (35\%) respondenti, konsultācijas ar prakses vadītāju notika katru dienu, tikpat daudz respondentu (35\%) norāda, ka prakses vadītājs ar viṇiem 
ticies reti. Klīnisko speciālistu aizņemtība un nepieciešamība vienlaikus veikt gan pacientu aprūpes darbu, gan darbu ar studentiem, rada komunikācijas un izglïtošanas grūtỉbas.

Roku higiēna un citi infekciju kontroles pasākumi ne vienmēr tika realizēti pilnā apjomā. Saskaroties ar pacienta bioloǵiskajiem šksidrumiem, aprūpes personāls roku dezinfekciju veica pirms katras procedūras 18 (45\%) gadijumos; 20 (50\%) respondenti norāda uz cimdu lietošanu, neveicot roku higiēnu.

Secinājumi. Pacientu identifikācijas procedūra ne visos gadījumos tiek realizēt pietiekami korekti. Tādi infekciju kontroles pasākumi, kā roku higiēna, atbilstoša cimdu lietošana, aprīkojuma dezinfekcija netiek realizēta pilnā apjomā. Vadlīniju, drošǐbas instrukciju, medikamentu drošas izmantošanas dokumentācijas pieejamība ir ierobežota. Lai uzlabotu pacientu drošỉbas jautājumu apguvi studiju procesā, nepieciešams katru gadu izvērtēt studentu klīniskajā praksē novērotos pacientu drošîbas aspektus. 


\section{TIESU MEDICĪNAS EKSPERTĪZES UN LABORATORISKĀ DIAGNOSTIKA}

\section{Rolands Brencāns, Alevtīna Leice}

Latvijas Universitātes P. Stradiṇa medicīnas koledža, Jūrmala, Latvija

Ievads. Dabas zinātnes, tehnoloǵijas, jaunas pētniecības metodes, kā arī zināšanas par traumām un slimībām, paver iespējas juridiskā praksē izzināt krimināllietu un civillietu būtību un noteikt nozieguma cēloṇus. Tiesu medicīna aplūko galvenokārt jautājumus, kas saistīti ar dažādu faktoru radītiem veselības traucējumiem un nāvi (O. Teteris 2004).

Darba mērķis. Veikt padziḷinātu izpēti tiesu medicīnas darba specifikā, inovācijām tiesu medicīnas laboratoriju izmeklēšanas gaitā un datu analīzē tiesu medicīnā Latvijā no 2016. līdz 2018. gadam.

Pētījumu metodologiskais apraksts. Pētījums par tiesu medicīnas aktualitātēm un tiesmedicīniskajām ekspertīzēm Latvijā tika veikts laika posmā no 2016. gada līdz 2018. gadam. Saskaṇā ar pētījuma mērḳi un pētījumu uzdevumiem tika izmantotas vairākas pētī̌sanas metodes. Teorētisko atziṇu izzināšanai tika izmantotas literatūras analīze un dokumentu izpēte. Kā galvenie avoti izcel̦ami Valsts tiesu medicīnas ekspertīzes centra publiskais pārskats (2016. g., 2017. g., 2018. g.), mācību un izziṇas līdzeklis “Tiesu medicīnas esence” (O. Teteris 2004). Kopā pētījumā, datu statistiskai analīzei, tika izveidoti attēli un tabulas, kas atspoguḷoja tiesu medicīnas darbības rezultātus un tiesu medicīnas ekspertīzes un izpètes 2016.-2018. gadā Latvijā.

Pētijumu rezultātu interpretācija. Pētījumā noteikts, ka visstraujāk izmeklēto objektu skaits tiesu medicīnas laboratorijās Latvijā pieaug tiesu medicīnas kriminālistikas laboratorijā. Izmeklēto objektu skaits 2018. g. salīdzinājumā ar 2016. g. audzis par 19\% (515 vienībām); (2018. gadā izmeklēto objektu skaits 2631 vienības, bet 2016. g. 2116 vienības). Izmeklēto objektu skaits tiesu medicīnas laboratorijās izteikti samazinājies tiesu toksikolog̣ijas laboratorijā par 12,2\% (2017. g. tika izmeklēti 4292 objekti, savukārt 2018. g. - 3760 objekti), bet ekspertī̌u un izspēšu skaits audzis par 1141 vienībām. Ekspertīzes un izpētes skaita pieaugums 2018. g., salīdzinot ar 2017. g., par 824 vienībām (2017. g. 18136 ekspertīzes un izpētes, savukārt 2018. g. 18960 ekspertīzes un izpētes) tiesu medicīnas laboratorijās skaidrojams ar toksikoloǵijas laboratorijā pieņemtajiem lēmumiem par tiesu medicīniskās ekspertīzes noteikšanu uzdotajiem jautājumiem par apreibinošo vielu klātbūtni mirušo biologiskajā materiālā.

Latvijas tiesu medicīnas praksē tiek ieviestas un izmantotas jaunas un zinātniski pamatotas metodes, kas ḷauj tiesu medicīnai attīstīties ar citām nozarēm un 
tehnologijām, kas ar to ir saistītas. Latvijas tiesu medicīna progresē un citu medicīnas nozaru vidū tiek uzsvērta, nostiprinoties likumdošanas varai.

\section{Secinājumi}

1. Ekspertīzes un izpētes skaita pieaugums 2018. g., salīdzinot ar 2017. g., audzis par 824 vienībām.

2. Kopumā tiesu medicīnas genētikas un serologijas laboratorijā ekspertīžu lēmumi kriminālprocesā 2018. gadā, salīdzinot ar 2017. gadu, skaits audzis par 96 vienībām.

3. Tiesu medicinas kriminālistikas laboratorijā izmeklēto objektu skaits 2018. g. audzis par 492 vienībām, salīdzinot ar 2017. gadu.

4. Tiesu toksikologijas laboratorijā izmeklēto objektu skaits 2018. gadā, salīdzinot ar 2017. gadu, samazinājies par 532 vienībām, bet ekspertīžu un izpēšu skaits audzis par 1141 vienībām. 


\section{KLASISKĀS KĀJU MASĀŽAS PIELIETOJUMS BALETDEJOTĀJĀM SKELETA MUSKUL̦U TRAUMU PROFILAKSEI}

\section{Germans Ševčenko, Jolanta Pupure}

Latvijas Universitātes P. Stradiṇa medicīnas koledža, Jūrmala, Latvija

Ievads. Baletdejotāju darbs sevī apvieno gan mākslu, gan sportu, kas prasa ārkārtēju fizisku spēku, lokanību un izturību. Baletdejotājiem ir liels risks iegūt dažādus skeleta muskul̦u bojājumus, no kuriem biežākie ir stilba kaula un metatarsālā kaula stresa lūzumi (Smith et al., 2016). Pēdu un potǐšu traumas īpaši skar tieši baletdejotājas, jo puantes absolūti nav paredzētas pareizai pēdu anatomiskajai slodzei (Vosseller et al., 2019; Lopez-Lopez et al., 2020).

Pēdējo gadu pētijumi rāda, ka baletdejotājas sāpju mazināšanai lieto nesteroìdos pretiekaisuma līdzekḷus, un traumu gadījumos viņām bieži veic operācijas, kineziolog̣ijas teipošanu un fizioterapijas rehabilitācijas kursus (Wentzell, 2018; Vosseller et al., 2019). Turklāt baletdejotāju traumu profilaksei tiek ieteikti atviegloti fiziskie treniņi un pilnvērtīgās uzturs (Russell, 2013). Masāžas piemērošana baletdejotājām dažādu pēdu un potišu traumu profilaksei un muskuļu krampju mazināšanai pēdējā laikā nav pētîta.

Darba mērḳis. Pētijuma mērḳis ir noskaidrot klasiskās kāju masāžas ietekmi uz baleta mākslinieču organismu.

Materiāli un metodes. Pētijumā piedalijās piecas Latvijas Nacionālās operas un baleta baletdejotājas, kurām veica klasisko kāju masāžu kursu divas reizes nedēḷā, kopā sešas reizes, 45-50 min. Tika veikta kvalitatīva strukturēta intervija katrai pētījuma dalībniecei pirms un pēc masāžas kursa. Intervijā respondentes atbildēja par biežākajām sūdzībām, piemēram, kāju tūsku, smaguma sajūtu un krampjiem, kuras ikdienā traucē darbam. Papildus tika pielietota arī sāpju skalu (Wong-Baker, 2008).

Rezultāti. Pirms masāžas kursa uzsākšanas respondentes norādijja, ka ikdienā saskaras ar dažādām mikrotraumām, smaguma sajūtu kājās, tūsku, krampjiem un miega traucējumiem. Pēc masāžas kursa visām baletdejotājām novēroja uzlabojumus, ko viņas raksturoja kā sāpju samazināšanos (sāpju skalā no vidēji 3,8 pirms masāžas kursa līdz 0,6 pēc masāžu kursa). Smaguma sajūta kājās trīs respondentēm samazinājās un divām vairāk nebija novērota pēc masāžām. Visas atzina, ka bija mazinājusies kāju tūska un krampju biežums, kāa arī uzlabojās miegs.

Secinājumi. Šajā pētījumā iegūtie dati pirmo reizi parādīja, ka masāžas kurss labvēlīgi ietekmē baletdejotāju organismu. Mēs ierosinām, ka klasiskā kāju masāža varētu tikt iekḷauta baletdejotāju treniņu programmās, lai mazinātu traumu risku 
un uzlabotu dejotāju sniegumu, kā arī radītu jaunas darba vietas masieriem. Lai precizētu masāžas pozitīvos efektus baletdejotājām, ir nepieciešami turpmāki un plašāki pētījumi. Šāda veida anketas varētu izmantot pašnovērtēšanas testiem, kas l̦autu baletdejotājām savlaicīgi vērsties pie masāžas speciālista, lai mazinātu traumu risku.

\section{LITERATŪRA}

1. Smith TO, Davies L, de Medici A, Hakim A, Haddad F, Macgrego A. Prevalence and profile of musculoskeletal injuries in ballet dancers: A systematic review and metaanalysis. Phys Ther Sport 2016; 19:50-56.

2. Vosseller JT, Dennis ER, Bronner S. Ankle Injuries in Dancers. J Am Acad Orthop Surg, 2019; 27(16):582-589.

3. López-López D, Fernández-Espiño C, Losa-Iglesias ME, Calvo-Lobo C, RomeroMorales C, Rodríguez-Sanz D, Navarro-Flores E, Becerro-de-Bengoa-Vallejo R. Women's Foot Health-Related Quality of Life in Ballet Dancers and Nondancers. Sports Health, 2020; 12(4): 347-351.

4. Wentzel M. Conservative management of a chronic recurrent flexor hallucis longus stenosing tenosynovitis in a pre-professional ballet dancer: a case report. J Can Chiropr Assoc, 2018; 62(2):111-116.

5. Russell JA. Preventing dance injuries: current perspectives. Open Access J Sports Med, 2013; 4:199-210.

6. Wong-Baker FACES Foundation (2018). Wong-Baker FACES ${ }^{\circledast}$ Pain Rating Scale. Retrieved [Date] with permission from http://www.WongBakerFACES.org. 


\title{
ATBILDĪGA ANTIBAKTERIĀLO LĪDZEKL̦U LIETOŠANA SABIEDRĪBĀ
}

\author{
Inga Kauliṇa ${ }^{1,2}$, Olga Rozentāle $e^{1,2}$ \\ ${ }^{1}$ Latvijas Universitātes P. Stradin,a medicīnas koledža, Jūrmala, Latvija \\ 2 P. Stradina Klīniskā universitātes slimnīca, Rīga, Latvija
}

Ievads. Vajadzība pēc antibakteriālās terapijas ir praktiskās medicīnas neatṇemama realitāte, bet, neievērojot to pareizu lietošanu, tiek veicināta mikrobu rezistence. (Bērziņa, 2007) Mikroorganismu rezistence ir kḷuvusi par vienu no mūsdienu centrālajām problēmām. (Biksone, Behmanis, 2016) Antibiotiku nepamatota lietošana ir galvenais riska faktors, kāpēc veidojas rezistence. Aptuveni $75 \%$ no antibiotikām lieto ambulatori un pētijumi rāda, ka tieši šajā sektorā tās visbiežāk arī tiek lietotas nelietderīgi. (Dumpis, 2009) Antibakteriālā rezistence ik gadu Eiropā izraisa 33000 nāves gadījumu. Lielāko šo nāves gadījumu skaitu būtu iespējams novērst, apturot antibakteriālo līdzekḷu nepamatotu izmantošanu. Arī Eirobarametra pētījums liecina, ka jāvelta lielākas pūles, lai vairotu iedzīvotāju informētību un zināšanas par antibakteriāliem līdzekḷiem. (Eiropas Komisija, 2018)

Darba mērḳis. Noskaidrot sabiedrības izpratni par atbildīgu antibakteriālo līdzekḷu (turpmāk tekstā - AB) lietošanu.

Materiāli un metodes. Pētijums veikts, izmantojot kvantitatìvo pētijuma metodi, instruments - autoru izstrādāta aptaujas anketa. Pētijuma ietvaros (2020. g. marts-aprīlis) tika analizētas 100 stacionāra pacientu atbildes.

Rezultāti. Pēdejjā gada laikā 30\% respondentu ir lietojuši AB. 82\% respondentu $\mathrm{AB}$ ir iegādājušies aptiekā pēc ārsta izrakstītas receptes, bet 18\% AB ieguva bez ārsta receptes. $23 \%$ respondentu mājsaimniecībās ir $A B$ rezerves. Respondentu viedoklis par $\mathrm{AB}$ lietošanas vajadzību: $24 \%$ tās lietotu pie vīrusu infekcijas, 3\% sāktu lietot pie paaugstinātas temperatūras, $2 \%$ lietotu iesnu gadījumā un $5 \%$ lietotu profilaktiski. $A B$ terapijas kursu ievēro $71 \%$, bet $21 \%$ to pārtrauc, tiklīdz veselības stāvoklis uzlabojas. 66\% zina, ka, nepareizi lietojot $\mathrm{AB}$, veidojas mikrobu rezistence, $30 \%$ neko nav dzirdējuši par nepareizas $A B$ lietošanas sekām, bet $4 \%$ uzskata, ka nekāds kaitējums netiek nodarìts. $\mathrm{AB}$ lietošanu tikai pēc ārsta nozīmējuma par svarīgu uzskata 99\%. Ievērot ārsta nozīmēto ārstēšanas kursu par svarīgu uzskata $89 \%$, par mazsvarīgu - 9\%, bet $2 \%$ uzskata, ka tas nav svarīgi. Ievērot vienādus laika intervālus starp medikamenta lietošanas reizēm par svarīgu uzskata 74\%, par mazsvarīgu $-13 \%$, nav svarīgi $-6 \%$ un $7 \%$ nav viedoklis.

Secinājumi. Respondentu zināšanas par dažādiem ar pareizu AB lietošanu saistītiem aspektiem ir nepietiekamas. Rezultātā $\mathrm{AB}$ var tikt izmantotas ne tikai bez ārsta ziņas, bet arī nepareizi, t.i., nesaṇemot optimālu medikamenta devu, neievērojot 
lietošanas intervālu un ārstēšanas kursu. Tādējādi pakḷaujot sevi nelabvēlīgai $\mathrm{AB}$ darbībai un veicinot antibakteriālās rezistences attīstību. Izglīīiba ir nozīmīgs instruments, lai izmainītu profesionāḷ un sabiedrības attieksmi pret atbildīgu un piesardzīgu antibiotiku lietošanu un antimikrobiālās rezistences jautājumiem. Ko varētu risināt, aptiekā kopā ar izrakstīto $\mathrm{AB}$ pacientam izsniedzot arī informatīvu bukletu. Darba ietvaros autores ir izstrādājušas šādu bukletu.

\section{LITERATŪRA}

1. Bērziṇa S., 2007. Informatīvi dati par antibiotiku patēriṇu Latvijā. Doctus. Iegūts no: https://www.doctus.lv/2007/6/informativi-dati-par-antibiotiku-paterinu-latvija [skatits: 27.05.2020.]

2. Biksone G., Behmanis A. 2016. Solis pa solim pacientu konsultēšanā. Rīga: SIA Aptieku apvienība, 561. lpp.

3. Dumpis U., 2009. Klīniskās prakses pieredze. Latvijas antibiotiku patēriņš un rezistence. Doctus. Marts

4. Eiropas Komisija. 2018. Eiropas Antibiotiku informācijas diena 2018: mums jāapvieno spēki, lai novērstu antibiotiku nepamatotu izmantošanu. Ec.europa. Iegūts no: https:// ec.europa.eu/latvia/news/eiropas-antibiotiku-inform\%C4\%81cijas-diena-2018mums-j\%C4\%81apvieno-sp\%C4\%93ki-lai-nov\%C4\%93rstu-antibiotiku_lv [skatīts: 28.01.2020.] 


\title{
VESELĪBAS UN APRŪPES PROBLĒMAS BĒRNIEM AR MARFĀNA SINDROMU
}

\author{
Signe Ašuka', Rita Geske ${ }^{2}$ \\ 1 Neatliekamās medicīniskās palīdzības dienests, Zemgales reǵionālais centrs, \\ Viesīte, Latvija \\ 2 Latvijas Universitātes P. Stradiṇa medicīnas koledža, Jūrmala, Latvija
}

Ievads. Marfāna sindroms (MFS) ir pārmantota un reta slimība. Tā ir monogēnā dominantā slimība ar incidenci 2-3 / 10 000. Pēc Bērnu klīniskās universitātes slimnīcas reto slimību koordinācijas centra datiem (BKUS RSKC, 2019) Latvijā ir reg̣istrēti divpadsmit bērni ar diagnozi Marfāna sindroms. Marfāna sindromu izraisa defektīvs gēns, kas vada fibrillīna (FBN) sintēzi organismā.

Šì slimība var iztaisìt dažādas pakāpes bojājumus jebkurā k̦ermeṇa orgānu sistēmā, tomēr galvenokārt šis sindroms skar trīs sistēmas - skeleta, redzes un kardiovaskulāro. Pirmās redzamās izmainas ir skeleta sistēmā - garš, tievs augums, kaulu deformācijas. Sirds un asinsvadu sistēmā var būt nopietnas, dzīvībai bīstamas izmaiņas, piemēram, aortas aneirisma. Redzes sistēmas galvenās izmaiņas ir lēcu dislokācija un tuvredzība, var būt arī tīklenes atslān,ošanās un agrīna glaukoma.

Bērnam ar diagnozi - Marfāna sindroms ir fiziskās attīstības izmaiṇas, kuru rezultātā bērnam rodas arī psihoemocionālas problēmas. Marfāna sindromu nepieciešams skatìt gan veselības, gan sociālās aprūpes kontekstā, jo saslimšana ar to būtiski izmaina pacientu dzīves kvalitāti. Preventīvie pasākumi dod garantiju, ka laikus tiks pamanitas nopietnas izmainas bērna ķermenī un laikus tiks uzsākta ārstēšana.

Darba mērkis. Izpētīt veselības un aprūpes problēmas bērniem ar Marfāna sindromu.

Materiāli un metodes. Literatūras analīze, kvalitatīvā pētniecỉbas metode - intervijas ar slimo bērnu vecākiem, ğimenes ārstiem un skolu māsām.

\section{Rezultāti}

1. Pēc pētỉjuma datiem MFS lielākai dal̦ai diagnosticēja zìdaiņa vecumā, bet dažiem tas tika diagnosticēt skolas vecumā.

2. Veselības problēmas bērniem tiek atpazìtas, uzsākot skolas gaitas. Lielākoties tās saistîtas ar kaulu un locìtavu sistēmas izmaiņām (sāpes locìtavās, mugurkaula, krūšu kurvja deformācijas, zobu un žokḷa deformācija). Daudziem ilgstoši zemā pašvērtējuma un mobinga dēḷ pievienojas arī psihosociālas veselības problēmas.

3. Viena no būtiskākajām aprūpes problēmām bērniem ar MFS ir viṇu vecāku zināšanu trūkums par šo slimību. Pēc vecāku domām, informācijas par MFS, 
tās radītajām veselības problēmām un preventīvajiem pasākumiem, kas sniegtu skaidru ieskatu MFS, latviešu valodā ir l̦oti maz.

Secinājumi. Bērnam ar MFS ir svarīgi laikus veikt preventīvos pasākumus atbilstoši bērna vecumam, lai dzīves laikā veselības problēmas nepadziḷinātos un nerastos dzīvībai bīstamas komplikācijas. Vēlams sastādīt ārstēšanas un aprūpes individuālo plānu. Ikdienā nepieciešams veltìt pastiprinātu uzmanību bērna aktivitātēm, jo bērnam ar MFS nepieciešams ievērot fizisko aktivitāšu ierobežojumus. Lai sekmētu informētību par MFS preventīiem pasākumiem, darba autore ir izveidojusi informatīvo materiālu. 


\title{
MIKROFLORAS IZVĒRTĒJUMS UZ ROKĀM AR GREDZENIEM
}

\author{
Rūta Melbārde-Vāvere, Jeḷena Urbēna, Ilze Briža \\ Latvijas Universitātes P. Stradina medicīnas koledža, Jūrmala, Latvija
}

Ievads. Viens no būtiskākajiem ar veselības aprūpi saistītu infekciju (VASI) novēršanas pasākumiem ir adekvāta roku higiēna. Lai roku higiēna tiktu veikta kvalitatīvi, nepieciešams izvairīties no roku higiēnas barjerām - gariem, lakotiem vai mākslīgiem nagiem un rotaslietām uz rokām. Pretējā gadījumā roku higiēna netiek veikta pilnvērtīgi, piemēram, zem gredzeniem saglabājas mikroorganismi, kas kontakta transmisijas cel̦ā var tikt nodoti pacientam vai pārnesti uz virsmām.

Darba mērķis. Veikt mikrofloras izvērtējumu uz rokām ar gredzeniem un salīdzināt rezultātus ar uzsējumiem no rokām bez gredzeniem.

Materiāli un metodes. Metode - eksperimentālā, salīdzinošā. Pētījuma instruments - pētījuma protokols. Pētijuma bāze - medicīnas koledža. Pētījuma periods no 24.02.2020 līdz 27.02.2020. Respondenti - $10(n=10)$ studenti. Pētījumā tiek veikti 40 paraugu uzsējumi uz hromogēnā krāsu agara no 10 respondentu rokām. No viena respondenta tiek ņemts uzsējums no vienas rokas ādas zem gredzena un otras rokas ādas bez gredzena. Pēc tam respondenti veica roku mazgāšanu ar ziepēm un ùdeni, pēc kā tika atkārtota paraugu ņemšana.

Rezultāti. Visiem pētījuma dalībniekiem uz rokām tika konstatēti koagulāzes negativie Staphylococcus spp., Sarcina spp. un Gram pozitīvas aerobas nūjiñas. Mikroorganismi tika identificēti, veicot preparātu pagatavošanu un krāsošanu pēc Grama metodes. Gram pozitīvi Staphyloccocus tika veikts plazmas koagulāzes tests, kurš visiem pārbaudītiem paraugiem bija negativvs. Pētījumā netika konstatēts Staphylococcus aureus, nefermentējošas Gram negatīvas baktērijas vai Enterobacteriaceae dzimtas baktērijas.

Pēc roku mazgāšanas vidēji par 24\% samazinās laukums, uz kura aug mikroorganismi, paraugos no rokas bez gredzena. Vidēji par 49\% ir samazinājies mikroorganismu daudzums, kas kolonizē ādu zem gredzena, pēc roku mazgāšanas veikšanas. Mikroorganismu skaita samazināšanās atspoguḷo roku higiēnas nozīmi. Konstatēta arī sakarība starp to, cik ciešs ir gredzens, jo pētījuma dalïbniekiem, kuru dalības numuri bija 3, 4, 5, 7 un 9, gredzens bija vaḷigs, un to viegli varēja kustināt, lai uzlabotu roku mazgāšanas efektivitāti.

Secinājumi. Uz visiem paraugiem tika izolēti koagulāzes negatīvie Staphylococcus spp., Sarcina spp. un Gram pozitīvas aerobas nūjiņas, tomēr paraugos, kas ņemti no ādas zem gredzeniem šie mikroorganismi tika izolēti lielākā daudzumā, nekā paraugos, kas ņemti no ādas bez gredzena. 
Izdalīto mikroorganismu daudzumā nozīme ir arī gredzenu stingrībai un vai, veicot roku mazgāšanu, ir iespējams gredzenu nobìdīt, jo pētījuma dalībniekiem, kuru gredzenus varēja nobīdìt ir daudz mazāk izdalīto mikroorganismu pēc roku mazgāšanas, nekā dalībniekiem, kuru gredzenus varēja nobīdīt minimāli.

Uz rokām esošie gredzeni ir kā viena no barjerām, kas var ietekmēt roku higiēnas kvalitāti. Pētījumā parādās, ka mikrofloras daudzums zem gredzeniem ir lielāks, procedūras laikā kontakta transmisijas laikā mikroorganismi, var tikt nodoti tālāk, palielinot infekciju riskus. Tādēl ne tikai veselības aprūpē, bet arī skaistumkopšanas nozarē personālam ir jāpievērš pastiprināta uzmanība, lai samazinātu barjeru ietekmi uz kvalitatīvu roku higiēnu, tādējādi samazinot infekciju riskus. 


\section{DEKORATİVĀS KOSMĒTIKAS OTU MAZGĀŠANAS UN DEZINFEKCIJAS LĪDZEKL̦U EFEKTIVITĀTE}

\section{Kristiāna Laila Lazdiṇa ${ }^{1}$, Elvīra Lavrinoviča ${ }^{1,2}$}

1 Latvijas Universitātes P. Stradiṇa medicīnas koledža, Jūrmala, Latvija

2 Rīgas Austrumu klīniskā universitātes slimnīca, stacionāra "Gailezers" laboratorija, Rīga, Latvija

Ievads. Dažādi ikdienas ieradumi, tai skaitā arī, dekoratīvās kosmētikas lietošana, var ietekmēt mikroorganismu populāciju, kas atrodas uz ādas. Lai gan cilvēka ādai ir gana daudz aizsargbarjeru, lai nepiel̦autu patogēno mikroorganismu vairošanos uz tās, tomēr gadỉjumos, kad ir samazināta imunitāte vai pat nelielas traumas var izraisīt pastāvīgās mikrofloras izmaiṇas, līdz ar to ir iespējams, ka veidosies iekaisuma elementi uz ādas. Tādēl ir svarīgi uzturēt tīrus visus priekšmetus, kas nonāk saskarē ar ādu, tai skaitā arī dekoratīvās kosmētikas otas. Pētỉjumu dati par kosmētisko līdzekḷu mikrobiologisko piesārņojumu ${ }^{1}$ liecina, ka Staphylococcus ir organisms, kas visbiežāk izolēts no kosmētikas. Tās pašas giints baktērija Staphylococcus aureus var ierosināt plašu ādas un mīksto audu infekcijas sākot no virspusējiem ādas bojājumiem (folikulìts, impetigo, konjunktivìts) līdz smagām invazīvām infekcijām (abscess, celulīts).

Darba mērḳis. Noskaidrot dekoratīvās kosmētikas otu mazgāšanas un dezinfekcijas līdzekḷu efektivitāti.

Materiāli un metodes. Laika periodā no 2021. gada janvāra līdz 2021. gada februārim pētijuma ietvaros tika ņemtas vienas personas individuāli lietotas 10 dekoratīiās kosmētikas otas - 5 lielas otas, paredzētas pūdera uzklāšanai, 5 mazas otas, paredzētas acu ēnu uzklāšanai, kas tika inficētas ar sejas ādas mikrofloru. Un 5 dekoratīvās kosmētikas otu tīrī̌̌anas līdzekḷi - 3 mazgāšanas līdzekli ar antibakteriālu iedarbību un 2 izsmidzināmi līdzekḷi ar antibakteriālu iedarbību. Pirms un pēc dekoratīvās kosmētikas otu attīin̄šanas, no katras otas tika veikti 2 uzsējumi - uz hromogēnā agara un Kolumbijas 5\% asins agara. Izaugušās kolonijas tika krāsotas pēc Gram metodes un veikta mikroskopija.

Rezultāti. Pēc dekoratīiās kosmētikas otu inficēšanas gan uz hromogēna, gan Kolumbijas asins agara novēro mērenu līdz masīvu koloniju augšanu ar 4 līdz 8 veida kolonijām, pēc dekoratīvās kosmētikas otu attīiršanas uz barotnēm - augšanu nenovēro vai tā ir niecīga līdz mērena. Veicot mikroskopiju, tika konstatēti Gram pozitīvi koki un nūjiņas.

Secinājumi. Lielākā daḷa mikroorganismu, kas piesārṇo dekoratīvās kosmētikas otas, ir cilvēka ādas patstāvīgā vai tranzitorā mikroflora. Uz dekoratīvās kosmētikas otām gan pirms, gan pēc tīrǐšnas tika konstatēti Gram pozitīi streptokoki, 
stafilokoki un Gram pozitīvas nūjiņas. Vismazāko antibakteriālo efektivitāti novēro pie izsmidzināmajiem dekoratīvās kosmētikas otu tīrīšanas līdzekḷiem, savukārt vislielāko efektivitāti uzrāda mazgāšanas līdzekḷi ar antibakteriālo iedarbību.

\section{LITERATŪRA}

1. Available from: https://onlinelibrary.wiley.com/doi/epdf/10.1111/j.1365-2710.1989. tb00217.x 


\section{HOSPITĀLO INFEKCIJU RISKI PODOLOGA PRAKSĒ}

\section{Laura Serafimoviča, Mārīte Saulīte}

Latvijas Universitātes P. Stradiṇa medicīnas koledža, Jūrmala, Latvija

Ievads. Hospitālās infekcijas ir viens no biežākajiem nevēlamajiem notikumiem veselības aprūpes sistēmā, kas nozìmīgi ietekmē sabiedrības veselību un dzìves kvalitāti (ESPKC, 2020). Šì problēma skar jebkuru ārstniecības iestādi, tajā skaitā arī podologa praksi. Podologiskās aprūpes procesā ar augstu kontaminācijas risku ir saistītas gan medicīniskās ierīces, gan manipulācijas, piemēram, ieauguša naga, pēdu plaisu, pēdu kārpu un kāju čūlu aprūpe u.c., tādēḷ viens no galvenajiem podologa uzdevumiem ir nodrošināt adekvātu un efektīvu infekciju kontroli (Bloß, 2019; Grünewald et al., 2015; Niederau, 2018; Yarets, a.o., 2013). Lai darbs podologa kabinetā būtu pēc iespējas efektīvāks hospitālo infekciju pārnešanas faktoru mazināšanā, nepieciešams ievērot infekcijas kontroles, higiēnas un pretepidēmijas pasākumus.

Darba mērķis. Noskaidrot hospitālo infekciju riskus podologa praksē.

Materiāli un metodes. Darbā izmantota medicīnas literatūras analīze, kvantitatīvā pētījuma metode - podologu aptauja un datu matemātiskā analīze. Pētījuma instruments: autoru izstrādāta strukturēta anketa, kurā iekḷauti 19 jautājumi ar piedāvātiem atbilžu variantiem, kas vērsti, lai noskaidrotu iespējamos hospitālo infekciju riskus un veikto infekcijas kontroles barjeras nodrošinājumu podologu praksēs. Respondentu skaits $n=60$.

Rezultāti. Hospitālā infekcija ir polietologisiska saslimšana, ko veicina dažādi riska faktori, un ikviens var tikt pakḷauts inficēšanās riskam gan endogēnā, gan eksogēnā cel̦ā. Izsaucēji ir dažādu taksonomisko grupu pārstāvji (baktērijas, vīrusi, sēnītes, vienšūṇi), kur īpaša uzmanība jāpievērš multirezistentajiem mikroorganismiem, piemēram, pret vankomicīnu un metacilīnu rezistentajam Staphylococcus aureus Podologa praksē svarīgākās ierosinātāju grupas ir ne tikai baktērijas, bet arī vīrusi - papilomvīrusi, hepatītvīrusi, HIV (Grünewald et al., 2015; Ruck, 2007).

Pētījuma rezultāti liecina, ka 92\% aptaujāto podologu instrumentu dezinfekciju un sterilizāciju veic paši, bet $8 \%$ gadījumu to veic apmācīts personāls, pilnībā izslēdzot ar instrumentu kontamināciju saistītos hospitālās infekcijas riskus podologu praksēs. Arī infekcijas kontroles pasākumi tiek veikti visās (100\%) podologu darbavietās. Vairākumā gadījumu (65\%) infekcijas kontroles pasākumus veic pats podologs, bet apmācīts personāls vai jaunākais medicīnas personāls to veic 35\% gadijumu. 
Nozīmīga loma hospitālo infekciju risku mazināšanā ir individuālo aizsarglīdzekḷu izmantošanai un pareizai roku higiēnai, jo tieši inficētas personāla rokas tiek uzskatītas par visbiežāko pārneses mehānismu (SPKC, 2016). Salīdzinoši liels skaits aptaujāto podologu (87\%) ikdienā veic roku higiēnisko dezinfekciju, savukārt 13\% podologu nepieciešams uzlabot roku higiēnas pasākumus, jo roku mazgāšana neaizstāj roku dezinfekciju pirms podolog̣isko manipulāciju izpildes.

\section{Secinājumi}

Infekciju riskam pakḷauto manipulāciju īpatsvars podologa praksē ir lielāks par pusi, tādēḷ podologiem savā darbā ir jāpievērš pastiprināta uzmanība hospitālo infekciju kontrolei un to ierobežošanai.

Podologi (98\%) savā darbā pievērš pastiprinātu uzmanību un veic risku mazinošas darbïbas darbavietas un izmantojamo instrumentu aseptikas pasākumos.

Individuālo aizsarglīdzekḷu izmantošana podologa praksēs ir atšķirīga, piemēram, darba apgeērbu valkā 90\% podologi, kas vērtējams kā riska faktors hospitālo infekciju izplatībai.

Kopumā podologi ir labi informēti par ikdienā veicamajām infekcijas kontroles darbībām, bet to pielietošana praksē ir atškirīga, kas liecina par nepieciešamību veikt izglītojošo darbu, lai novērstu hospitālo infekciju riskus podologa praksē.

\section{LITERATŪRA}

1. Bloß, M. 2019. Der einwachsende Nagel. Planegg: Verlag Neuer Merkur GmbH, $59-60 \mathrm{~S}$.

2. Eiropas slimibu profilakses un kontroles centrs. 2020. Infection prevention and control for the care of patients with 2019-nCoV in healthcare settings. Iegüts no: https:// www.ecdc.europa.eu/sites/default/files/documents/nove-coronavirus-infectionprevention-control-patients-healthcare-settings.pdf [sk. 20.06.2020].

3. Grünewald K., Von Rheinhaben, Fr., Feindt, S., 2015. Theorie der medizinischen Fussbehandlung. Band 2. München: Verlag Neuer Merkur GmbH, 459 S.

4. Niederau, A. 2018. The Big Book of Nail Deseases. 3rd ed. Planegg: Verlag Neuer Merkur $\mathrm{GmbH}, 31 \mathrm{p}$.

5. Ruck, H., 2007. "Handbuch fur die medizinische Fusspflege", Stuttgart: Hippokrates Verlag, 301 lpp.

6. Slimïbu profilakses un kontroles centrs. 2016. Ieteikumi ärstniecības iestāžu higiēniskā un pretepidēmiskā režìma plānu izstrādei. Paraugplāns. Rịga. Iegūts no: https://www. spkc.gov.lv/lv/ieteikumi-arstniecibas-iestadem-0/paraugplans_02-06-2020.pdf. [sk. 01.09.2020.].

7. Yarets, Y., Rubanov, L., Shevchenko, N. 2013. The biofilm forming capacity of staphylococcus aureus from chronic wounds can be useful for determing Wound-Bed Praparation methods. EWMA Journal.(13), 7-13 p. 


\section{DAŽĀDU DEZINFEKCIJAS LĪDZEKL̦U EFEKTIVITĀTE ROKU DEZINFEKCIJAI}

Margarita Blate ${ }^{1}$, Elvīra Lavrinoviča ${ }^{1,2}$

1 Latvijas Universitātes P. Stradiṇa medicīnas koledža, Jūrmala, Latvija

2 Rīgas Austrumu klīniskā universitātes slimnīca, stacionāra "Gailezers" laboratorija, Rīga, Latvija

Ievads. Saistībā ar SARS CoV-2 atkal aktualizējusies roku mazgāšana un dezinfekcija. Pèc Slimību profilakses un kontroles centra sniegtajiem statistikas datiem par 2020. gadu, gripa un citas akūtu augšējo elpceḷu infekcijas skārušas 5,5\% no kopējā Latvijas iedzīvotāju skaita. Turpinās SARS CoV-2 pandēmija. Ir stingri noteikti individuālie drošības līdzekḷi, kuri sevī iekḷauj fizisko distancēšanos, aizsargmasku nēsāšanu sabiedriskās vietās, roku un virsmu dezinfekciju un personīgo higiēnu (roku mazgāšanu, kas l̦autu ierobežot slimību izplatīšanos). Pēc SARS CoV-2 infekcijas plašākas izplatǐšanās iedzīvotāju starpā tiek pastiprināti lietoti dažādi dezinfekcijas līdzekḷi, lai sevi pasargātu no inficēšanās, līdz ar to nepieciešams izvēlēties tos dezinfekcijas līdzekḷus, kuri visefektīvāk veic savu funkciju, un kuri no tirgū pieejamajiem līdzekliem ir efektīvākie mikroorganismu un vīrusu iznīcināšanā.

Mērḳis. Salīdzināt trīs dažādu dezinfekcijas līdzekḷu efektivitāti pret roku ādas bakteriālo mikrofloru.

Materiāli un metodes. Uz Kolumbijas agara ar 5\% asins piedevu tika veikti uzsējumi no abām rokām 3 cilvēkiem ar nomazgājuma metodi pirms dezinfekcijas lïdzekḷa pielietošanas un pēc tam, kad rokas tika dezinficētas ar dezinfekcijas līdzekli. Pētijums tika atkārtots 3 dažādās dienas, pielietojot 3 atšķirīgus dezinfekcijas līdzekḷus. Uzsētās plates tika inkubētas $48 \mathrm{~h}$ termostatā pie temperatūras $36^{\circ} \mathrm{C}$. Pēc inkubācijas tika veikta koloniju izvērtēšana un saskaitǐšana, procentuāli izrēḳinot, cik daudz ir samazinājusies mikroorganismu augšana pēc dezinfekcijas līdzekḷa pielietošanas.

Rezultāti. Visas trīs dezinfekcijas līdzekḷi samazināja roku ādas mikrofloras daudzumu. Mikrofloras samazinājums variē no $89 \%$ līdz 17,8\%. Interesanti, ka procenti atšķīās ne vien starp dažādiem dezinfekcijas līdzekḷiem, bet arī starp pētỉjumā iesaistītajām personām, vēl pārsteidzošāks izrādijās fakts, ka samazinājuma procenti izrādijāas atškirīigi labajai un kreisajai rokai vienai un tai pašai personai.

Secinājumi. Iegūtie rezultāti parāda, ka visi trīs dezinfekcijas līdzekḷi ietekmē roku ādas bakteriālo mikrofloru, to skaitliski samazinot.

Pētijuma gaitā radās pārsteidzošs secinājums, ka l̦oti liela nozīme bija pētījuma dalībnieku praktiskai rīcībai, uzklājot dezinfekcijas līdzekli roku ādai. 
Visticamāk, līdzīga situācija veidojas šobrīd veikalos, aptiekās un citās iestādēs, kur cilvēki paši izmanto piedāvātās roku dezinfekcijas iespējas.

Izvērtējot iegūtos rezultātus, redzams, ka svarīgi veidot informācijas kampaņas par pareiziem roku mazgāšanas un roku dezinfekcijas paņēmieniem.

Veiktais pētījums uzskatāms kā pilotprojekts plašākam pētỉjumam, kura gaitā nepieciešams standartizēt pētijuma dalībnieku rīcību, uzklājot dezinfekcijas līdzekli. 


\section{VECMĀŠU DARBĪBAS ASPEKTI 19. GADSIMTĀ}

\section{Mārtiṇš Vesperis}

Paula Stradiṇa Medicīnas vēstures muzejs, Rīga, Latvija

Ievads. Vecmāšu darbības vēsturiskā pētniecība Latvijā līdz šim ir ḷoti maz skatīta un analizēta. Pirmais zināmais Latvijā vecmāšu zvērests datēts ar 1582. gadu, Rīgā. Pirmo mācību grāmata latviešu valodā sarakstījis Karls Johans Meiers 1783. gadā, kas saucas "Mācības priekš bērnu saṇēmējām”. 1809. gadā Krievijas Iekšlietu ministrija izdeva priekšrakstus par vecmāšu skolas izveidi katrā guberņā. Pirmā vecmāšu skola Vidzemes guberṇā tika atklāta 1819. gadā Tērbatas (Tartu) Universitātē. Kurzemes gubernā šāda skola tika izveidota 1826. gadā Jelgavā. Praktiski ar šo laiku var uzskatīt, ka tagadējā Latvijas teritorijā tika uzsākta profesionāla vecmātes aroda apguve, kas noteica noteiktus standartus izglītības un profesijas jomā, kā arī uzsāka izskaust neprofesionālu darbu šai jomā.

Darba pētījuma mērḳis. Izvērtēt un aktualizēt vecmātes izglīīibas un darbības atsevišksus aspektus 19. gadsimtā.

Materiāli un metodes. Paula Stradiṇa Medicīnas vēstures muzeja krājumā esošais vecmātes Annas Jostsones piezīmes, 19. gadsimta 2. pusē izdotie likumi par vecmātēm, publikācijas periodikā un izdotās mācību grāmatas vecmātēm. Izmantota vēsturiski salīdzināmā metode.

Rezultāti. Kurzemes guberņas Jelgavas vecmāšu skolai 1826. gadā tika izstrādāti arī noteikumi, kas noteica gan mācību ilgumu, valodu, kādā notiks apmācība, un saturu. Tāpat bija izveidoti noteikumi par to, kas var iestāties šai skolā, uzvedības noteikumi, kā arī kurš un cik lielā apjomā finansē un uztur jaunās mācekles. 19. gs. 2. pusē vecmāšu izglītošanu veicināja arī specializētās literatūras izdošana latviešu valodā, piemēram, Jelgavas vecmāšu skolas direktora dr. Teodora Dīteriha 1858. gadā izdotā mācību grāmata "Mācības grāmata savām mācītām latviešu bērnu saṇēmējām”. Pēc lielajām reformām Krievijas impērijā 19. gadsimta 60. gados tika izdoti arī dažādi likumi par vecmātēm. Tie jau noteica kārtību cik daudz vecmātēm jābūt pagastā, kādi apstākḷi tām jānodrošina, kādi līdzekḷi jāsniedz topošām vecmātēm, kādi pienākumi jāveic vecmātēm, viṇu nepieciešamais piederumu inventāra saraksts, atskaites formas, kā arī tika reglamentēti citi vecmāšu darbības aspekti.

Secinājumi. Vecmāšu skolām, kas darbojās tagadējā Latvijas teritorijā 19. gadsimtā, bija l̦oti nozīmīga loma profesionālu un izglītotu vecmāšu darbībai gan pilsētās, gan, īpaši, jau lauku reǵionos. Viens no skolu izveidošanas mērķiem bija mazināt jaundzimušo un māšu mirstību dzemdībās, kā arī izskaust neprofesionālu un izglītību neieguvušu bērnu saṇēmēju darbību. Izglītotu vecmāšu pieaugums lauku teritorijās vecināja kvalitatīvu un profesionālu pakalpojumu sniegšanu, ko regulēja 
gan īpaši izdotie likumi vecmātēm, gan arī izdotā specializētā literatūra. 19. gadsimta beigās praktiski katrā Latvijas lielākā pagastā bija algota izglìīibu ieguvusi vecmāte, kuru rezultātā pamazām tika izskaustas profesionālu izglìtỉbu neieguvušas bērnu saṇēmējas vai personas, kas uzdevās par vecmātēm.

Kopsavilkums. Vecmāšu izglitîbas politika, izdotie likumi vecmāšu darbïbai un sniegto pakalpojumu uzraudzī̌sana 19. gadsimtā noteica šīs profesijas prestiža celšanu un sniegto pakalpojumu kvalitātes celšanu. Radītie nosacijumi ir pamats tālākai vecmāšu profesijas un vecmāšu izglìitibas attīstībai gan 20. gadsimtā, gan arī 21. gadsimtā. 


\title{
MALNUTRĪCIJAS IETEKME UZ TRAUMATOLOGIIJAS UN ORTOPËDIJAS PACIENTIEM STACIONĀRĀ
}

\author{
Valda Ametere ${ }^{1}$, Nadežda Bogdanova ${ }^{1}$, Inta Miķele ${ }^{1}$, Inga Priede ${ }^{1,2}$ \\ 1 Latvijas Universitātes Rīgas 1. medicīnas koledža, Rīga, Latvija \\ 2 SIA "Rīgas 2. slimnīca", Rīga, Latvija
}

Ievads. Pacientu īpatsvars ar malnutrīciju vai malnutrīcijas risku stacionāros ir augsts. Dažādos pasaules valstu pētījumos to skaits svārstās 13-70\% akūti stacionēto pacientu vidū. Nīderlandē malnutrīciju konstatēja 23,8\% stacionētiem pacientiem (Victora, 2008). Slimība ir bieži novērojama pacientiem ar traumām un ortopēdiskām saslimšanām, kas hospitalizēti operatīvai terapijai. No malnutrīcijas stacionāros cieš 20-50\% stacionēto pacientu (Ansons I., 2019).

Darba mērḳis. Noskaidrot malnutrīcijas ietekmi uz traumatoloǵijas un ortopēdijas stacionāra pacientiem.

Materiāli un metodes. Darbā izmantotas kvalitatīvās pētījuma metodes - novērošanas protokols ar standartizētu malnutrīcijas skrīninga metodi (Starptautiskais malnutrīcijas riska novērtēšanas sijājošās diagnostikas tests Nutritional Risk Screening NRS - 2002) un dal̦ēji autoru izstrādāta strukturēta intervija ārstiem, veselības aprūpes speciālistiem. Pētījumā piedalījās 67 stacionāra pacienti, t. sk. 22 vīrieši, 45 sievietes, un 12 veselības aprūpes speciālisti, kā arī medicīnas personāls - 9 māsas, 3 ārsti. Pētījums tika veikts 2020. gada aprīlī-maijā.

Rezultāti. Malnutrīcijas riskam traumatologiijas un ortopēdijas profila stacionārā ir pakḷauti 19,5\% pacientu, kas sakrīt ar citur Eiropā veikto pētijumu rezultātiem malnutrīcijas diagnostikā. Šajā pētījumā malnutrīcijas risks novērots tikai sievietēm. Lielākais risks konstatēts sievietēm vecuma grupā no 70 gadiem ar nepietiekamu barojumu, kā arī sievietēm vecuma grupā līdz 70 gadiem ar optimālu barojumu, veicot augšdelma apkārtmēra (MUST) mērījumu. Malnutrīcija negatīvi ietekmē pacienta atvesel̦ošanās periodu - ilgāka brūču dzīšana, augsts izgulējumu, infekciju, blakus slimību paasinājumu risks, vispārēja organisma veselības stāvokḷa pasliktināšanās, izsīkums, muskuḷu vājums, rehabilitācijas perioda pagarināšanās.

Secinājumi. Malnutrīcijas ietekmei īpaši ir pakḷauti pacienti ar gūžas vai augšdelma kaula kakliņa lūzumiem, gulošie pacienti ar nopietnām blakus saslimšanām pēc 70 gadu vecuma, ko apstiprina gan veselïbas aprūpes speciālistu, gan veiktās pacientu novērtēšanas rezultāti. Agrīna malnutrīcijas problēmas novērtēšanas testa ieviešana veselības aprūpē uzlabotu malnutrīcijas diagnostiku, samazinot komplikāciju rašanās biežumu, hospitalizācijas laiku un mirstības rādītājus. 
Rekomendācijas. Pielāgot un ieviest Latvijas stacionāros starptautisko malnutrīcijas riska novērtēšanas sijājošās diagnostikas testu Nutritional Risk Screening NRS - 2002.

\section{LITERATŪRA}

1. Victora C. G. (2008) Maternal and child undernutrition: consequences for adult health and human capital // Lancet 2008; 371 (9606): 340-357 Retrieved from: https:// www.sciencedirect.com/science/

2. Ansons I. (2019) Pansionātos dzīvojošo veco l̦aužu malnutrīcijas riska novērtējums. Pieejams: https://www.doctus.lv/2019/12/pansionatos-dzivojoso-veco-lauzumalnutricijas-riska-novertejums. 


\title{
SAREŽḠ̣JUMI RECEPŠU MEDIKAMENTU IZSNIEGŠANĀ ATVĒRTA TIPA APTIEKĀS
}

\author{
Kitija Bērziṇa, Ruta Kidika, Kārlis Mačāns
}

Latvijas Universitātes Rīgas 1. medicīnas koledža, Rīga, Latvija

Ievads. Sarežğỉjumi recepšu medikamentu izsniegšanā aizvadīto gadu laikā ir pieauguši, īpaši tas bija jūtams 2020. gadā. Jauna kompensējamo zāḷu sistēma Latvijā sāka darboties ar 2020. gada 1. aprīli, un jaunā kārtība nosaka, ka pacientam tiek izsniegts lētākais medikaments, tādējādi krietni ietaupot pacienta līdzekḷus. Pārmaiņas kompensējamo zāļu sistēmā bija saistītas ar zināmam grūtībām, jo pandēmija nav ḷāvusi ar izmaiṇām rūpīgi iepazīstināt visas iesaistītās puses - ārstus, farmaceitus, farmaceita asistentus un pacientus. Pārāk biežā references medikamentu maiņa neatvieglo darbu, rada vairāk sarežǵījumu un lieku laika patēriṇu. Liela daḷa klientu ir neapmierināta ar iepriekš lietoto zāḷ maiṇu, ko apstiprina lēmumi izṇemt no Latvijas tirgus vairākus medikamentus. Medikamentu nepieejamību ietekmē arī SARS-CoV-2019, sarežǵijumus joprojām rada slikti funkcionējošā e-veselības sistēma. Arī saistībā ar e-recepti pacientiem ir neskaidrības un informācijas trūkums, piemēram, kā saņemt medikamentu, ja e-recepte izrakstìta citai personai un tamlīdzīgi.

Darba mērḳis. Noskaidrot, kādas problēmas var rasties aptiekas darbā saistībā ar recepšu zāḷu izsniegšanu.

Materiāli un metodes. Darbā tika izmantota kvantitatīvā pētniecības metode: anketēšana. Anketu ar 26 jautājumiem izstrādāja darba autore. Respondenti tika lūgti atbildēt par dažādām situācijām, kas ikdienā rada sarežǵījumus, piemēram, traucējumi e-veselības portāla darbā, izmaiņas kompensējamo medikamentu izsniegšanā, klientu neinformētība par dažādiem ar medikamentu saņemšanu saistītiem jautājumiem un citu. Pētījums tika veikts 2020. gada augustā-septembrī interneta vidē, tajā piedalījās 175 farmaceiti un farmaceita asistenti, kā arī 16 aptieku vadītāji, kuri strādā atvērta tipa aptiekās Latvijā.

Rezultāti. Pētījuma rezultāti apliecina, ka 2020. gadā ir pieauguši sarežǵījumi, kas skar recepšu medikamentu izsniegšanu atvērta tipa aptiekās. Kā norāda 97,1\% aptaujāto farmācijas speciālistu, tieši jaunās kompensējamās zāḷu sistēmas ieviešana radīja papildu problēmas. Savukārt 94,3\% norāda, ka kompensējamo zāḷu saraksta ieviešanas dēl pieaudzis laiks, kas jāpavada, izsniedzot kompensējamos medikamentus. Papildus sarežǵỉjumus ieviesa arī pandēmijas izraisīts medikamentu trūkums. Kā norāda 51,4\% respondentu, tad šādi gadijumi ir bieži, bet 38,9\%, ka ḷoti bieži. 78,3\% atzīst, ka sabiedrībā trūkst informācijas par e-veselības portāla iespējām, piemēram, iespēja uzzināt e-receptes numuru, delegèèt personas recepšu zāḷu izṇemšanai. 
Secinājumi. Sarežǵỉjumiem, kas rodas recepšu zāḷu izsniegšanā, ir gan objektīivi, gan subjektīvi cēloṇi. Objektīvie cēloṇi saistìti ar jaunās zāḷ kompensācijas sistēmas ieviešanu un ìpaši - ar biežo references medikamentu saraksta maiņu. Subjektīvie cēloṇi visbiežāk saistīti ar klienta zināšanām un viedokli par savu veselības stāvokli. Veselība un ierasto zāḷu pieejamība vai nepieejamība hroniskiem slimniekiem ir loti sensitīvs jautājums un rada papildu izaicinājumus farmaceitiskajā aprūpè. Aptiekas klienti nav pietiekami labi vai vispār nav informēti, kā pareizi saņemt medikamentus citai personai, un sabiedrībā trūkst informācijas par medikamentu saņemšanas kārtību un e-veselības portāla sniegtajām iespējām. 


\section{VECMĀTES ATBALSTS UN IZGLITTOŠANAS VEIDI NEDZIRDĪGĀM GRŪTNIECËM UN DZEMDĒTĀJĀM}

\section{Amanda Medusone, Ineta Robina}

Latvijas Universitātes Rīgas 1. medicīnas koledža, Rīga, Latvija

Ievads. Novērojumi liecina, ka mūsdienās nedzirdīgām sievietēm Latvijā joprojām ir pieejams ierobežots informācijas apjoms par dzemdniecỉbu, un atbalsts medicinas iestādēs nav līdzvērtīgs dzirdīgo sieviešu aprūpei zīmju valodas iemaṇu trūkuma dẹḷ. Dzemdību nodạậs, kā arī ārpus tām medicinas personāls nepārzina zīmju valodu, tāpēc nespēj pilnvērtīgi izglìtot un atbalstīt nedzirdīgās gómenes pirmsdzemdību, dzemdību un pēcdzemdību periodā.

Darba mērḳis. Noskaidrot, vai Latvijas nedzirdīgām grūtniecēm un dzemdētājām ir nepieciešama atbalsta un izglìtošanas programma latviešu zīmju valodā.

Materiāls un metodes. Pētỉjumā tika izmantota kvantitatīvā pētniecības metode anketēšana un kvalitatīvā pētniecỉbas metode - intervēšana. Pētỉjums tika veikts laika posmā no 2019. gada 5. decembra līdz 2020. gada 29. maijam. Pētijumā tika anketētas $114(n=114)$ vājdzirdīgas un nedzirdīgas sievietes. Pielietojot kvalitatīvo pētījuma metodi, pētījumā tika intervētas $2(n=2)$ nedzirdīgo sieviešu atbalsta personas.

Rezultāti. Veiktais pētijums norāda, ka $97(n=97)$ respondentu no $114(n=114)$ uzskata, ka Latvijā vājdzirdīgām un nedzirdīgām sievietēm ir emocionāla atbalsta trūkums. Otrs nozīmīgākais negatīvais faktors ir komunikācijas barjera starp pacientu un veselības aprūpes sniedzēju; nedzirdīgām grūtniecēm un dzemdētājām ir grūtāk uztverama rakstiska informācija. $87(n=87)$ respondentu vēlētos izglītojošu informāciju saņemt zīmju valodā video formātā. $66(n=66)$ respondenti atbildēja, ka saskarsmē ar veselības aprūpes speciālistiem ir izjutuši komunikācijas šḳēršlus.

Secinājumi. Būtiskākais faktors, kas negatīvi ietekmē vājdzirdīgu un nedzirdīgu sieviešu integrēšanos sabiedrībā, ir komunikācijas barjera. Komunikācijas barjeras dēḷ klientes izjutušas emocionālu atbalsta trūkumu un uztraukumu. Latviešu zīmju valoda ir efektīvākais komunikācijas un izglìtošanas veids nedzirdīgām grūtniecēm un dzemdētājām. Veselības aprūpes iestādēm nepieciešams izstrādāt labas prakses vadlīnijas dzemdību nodạ̦ām par efektīvu atbalsta, komunikācijas un izglìtošanas veidu nedzirdīgām sievietēm grūtniecības laikā, dzemdībās un pēcdzemdību periodā. Aprūpes iestādēm sadarbībā ar Latvijas Nedzirdīgo savienību būtu nepieciešams nodrošināt iespēju vājdzirdīgām un nedzirdīgām sievietēm saņemt attālinātu surdotulka pakalpojumus, ierodoties dzemdību palīdzību iestādē. 
Tas palīdzētu precizēt informāciju par pacientu stāvokli un spētu viņām labāk izskaidrot ārstu norādījumus. Būtu vēlams izveidot Youtube.com kontu, piesaistot dzemdību speciālistus, kur izvietot informatīvus un pamācošus video materiālus latviešu zīmju valodā vājdzirdīgām un nedzirdīgām sievietēm. 


\title{
DZIIVES KVALITĀTES PAŠNOVĒRTĒJUMS PACIENTIEM AR OSTEOARTRĪTU
}

\author{
Liene Štikova, Alīna Kriviṇa \\ Latvijas Universitātes Rīgas 1. medicīnas koledža, Rīga, Latvija
}

Ievads. Eiropas Savienībā no osteoartrīta cieš vairāk nekā 103 miljoni iedzīvotāju. Tas ir viens no galvenajiem invaliditātes cēloṇiem un viena no biežāk sastopamām balsta sistēmas slimībām Latvijā. Osteoartrīts ir ceturtais invaliditātes cēlonis, liecina Latvijas medicīnas statistikas dati (Eiropas Savienībā uzsākts..., 2017).

Pēc statistikas datiem, vairāk nekā 21\% pieaugušo ASV (46,4 miljoni cilvēku) ir ziņojuši, ka viņiem ārsts ir diagnosticējis artrītu. Osteoartrīts ir otrajā vietā pēc išēmiskām sirds slimībām kā darba nespējas cēlonis vīriešiem vecumā virs 50 gadiem (Nevitt, Arden, 2015).

Hroniska locītavu slimība būtiski neietekmē pacienta mūža ilgumu, bet pakāpeniski sagrauj darbaspējas un mazina dzīves kvalitāti (Mārtinsone, Sudraba, 2016).

Darba mērķis. Noskaidrot osteoartrīta pacienta dzīves kvalitātes pašnovērtējumu.

Materiāls un metodes. Darbā tika izmantota kvantitatīvā pētniecības metode anketēšana. Pētījumā tika aptaujāti 100 ambulatorie pacienti. Pētījums tika veikts 2020. gada septembrī - oktobrī.

Rezultāti. No aptaujātajiem ambulatorajiem pacientiem $61 \%$ ir nodarbināti, no tiem 90\% strādā pilnu darba dienu. 84\% respondenti slimības dēl izjūt negatīvas emocijas - satraukumu, prieka un cerību trūkumu, vientulību, dusmas. Raksturīgākie simptomi, kuri ietekmē pašaprūpes spējas un rada pacientiem neapmierinātību, ir hroniskas, periodiskas sāpes 46\% respondentu un locìtavu stīvums - 35\%. Osteoartrīta simptomu dēl, 45\% respondentu atsakās no fiziskām aktivitātēm, 15\% no draugu un radu apciemošanas, 10-11\% no sabiedrisko pasākumu apmeklēšanas un ikdienas aktivitātēm. Neraugoties uz osteoartrītu, 43\% respondentu apmeklē sabiedriskos pasākumus 1-2 reizes gadā; $24 \%$ vienu reizi pusgadā, $17 \%$ pasākumus neapmeklē. Aptaujājot ambulatoros pacientus, tika noskaidrots, ka citu personu palīdzība ir nepieciešama 69\% respondentu. No aptaujātiem respondentiem 34\% nav problēmu saskarsmē ar citiem cilvēkiem, viņi ir pašpietiekami, $18 \%$ veiksmīgi pielāgojas slimībai, bet $12 \%$ samierinājušies ar esošo situāciju.

Secinājumi. Aptaujātie respondenti vērtē savu dzīves kvalitāti ḷoti atšķirīgi. Iespējams, tam ir dažādi skaidrojumi - osteoartrīta smaguma pakāpe, lietotā terapija, speciālistu un radinieku atbalsts, pacienta psihoemocionālais stāvoklis pirms diagnozes, blakusslimību esamība. Lai precīzi atbildētu uz šo secinājumu, būtu jāveic vēl viens pētījums ar lielāku respondentu skaitu. 


\section{LITERATŪRA}

1. Eiropas Savienībā uzsākts jauns klīnisks izmēgeinājums, kurā tiek pētīts, kā izmantot taukaudu cilmes šūnas, lai ārstētu sāpīgu un pašlaik neārstējamu slimību - osteoartrītu (2017).Pieejams:https://futurehealthbiobank.com/lv/plasaka-informacija-par-cilmessunu-uzglabasanu/uzsakts-jauns-kliniskais-petijums-par-osteoartrita-arstesanuizmantojot-cilmes-sunas/.

2. Mārtinsone K., Sudraba V. (2016). Veselības psihologija. Rīga: Rīgas Stradiṇa universitāte.

3. Nevitt M., Arden N. (2015). Osteoarthritis: Epidemiology. Retrieved from: https:// www.sciencedirect.com/science/article/abs/pii/S1521694205001087?via\%3Dihub 


\section{BIEŽĀKIE ELPCEL̦U CAURLAIDĪBAS NODROŠINĀŠANAS VEIDI NMPD VIDZEMES REG̣IONĀ 2019. GADĀ}

\section{Signe Barinska, Ineta Robiṇa}

Latvijas Universitātes Rīgas 1. medicīnas koledža, Rīga, Latvija

Ievads. Ik gadu no nespējas nodrošināt elpcelı caurlaidību pasaulē mirst ap 600 cilvēku, no kuriem $10 \%$ ir otorinolaringologiska patologija, bet pacientiem ar anatomiskām augšējo elpcelıu izmaiņām, kas apgrūtina trahejas intubāciju, ir 2,3\% un vairāk (Klīniskā anesteziolog̣ija un intensīvā terapija, 2017).

Mūsdienās cilvēki bieži izmanto neatliekamo medicīnisko palīdzību smagās un galēji smagās situācijās, bet pacienta elpceḷu nodrošināšanai katrā konkrētajā gadijumā NMPD darbiniekiem nereti atliek maz laika izvēlēties labāko elpceḷu nodrošināšanas veidu, lai nepię̧autu smadzeņu un audu hipoksiju. Tāpēc NMPD ir izstrādāti algoritmi, kurus tā personāls izmanto ikdienas darbā.

Darba mērḳis. Noskaidrot, kādi elpceḷu nodrošināšanas veidi tiek pielietoti un kāds bijis to pielietojuma rezultāts.

Materiāls un metodes. Darbā tika izmantota kvantitatīvā pētniecỉbas metode: medicīnisko dokumentu analīze (Neatliekamās medicīniskās palīdzības izsaukumu elektroniskā dokumentācija). Dati tika atlasīit, vadoties pēc manipulācijas koda un izmantojot Starptautisko slimību un veselïbas problēmu klasifikāciju: 04 (elpvada pielietošana) un/vai 08 (trahejas intubācija), un/ vai 09 (krikotireotomija). Pètijums tika veikts no 2020. gada 16. aprīia līdz 2020. gada 29. maijam. Pètījumā tika analizētas 115 elektroniskās izsaukumu kartes.

Rezultāti. Pēc apkopotajiem datiem 2019. gadā Vidzemes reǵionā neatliekamās medicīniskās palīdzības etapā biežāk elpceḷu nodrošināšanai pielietotās metodes orofaringeālā elpvada ievadǐšana 50\% un endotraheālā intubācija $41 \%$ gadījumu, taču $9 \%$ gadījumu orofaringeālā elpvada ievadǐšana nav devusi vēlamo rezultātu, tāpēc ir veikta arī trahejas intubācija.

Pētỉjums norāda, ka raksturīgākie izsaukumu iemesli ir: 26 gadījumos bezsamaņa, 13 gadijumos sirds aritmija, 6 gadijumos celı satiksmes negadijumi, 8 gadijumos krampji, 9 gadījumos elpošanas problēmas, 6 gadījumos paralīze, 5 gadỉjumos aizdomas par pašnāvības mēǵinājumu.

No analizētajām 115 elektroniskajām izsaukumu kartēm 51 (44\%) bija norāde par nesekmīgu kardiopulmonālo reanimāciju, 14 (12\%) - par sekmīgu kardiopulmonālo reanimāciju, 50 (43\%) reanimācijas pasākumi nebija nepieciešami. 
Secinājumi. Trahejas intubācija ir uzskatāma par vienu no prioritātēm kardiopulmonālajā reanimācijā. Neatliekamās medicīniskās palīdzības etapā biežāk pielietotie veidi - orofaringeālie elpvadi un endotraheālā intubācija. Pēc apkopotajiem datiem no 115 izsaukumiem, kuros bija jāveic elpcelıu nodrošināšana, mazāk nekā $25 \%$ gadījumos palīdzības izsaucējs nav spējis paskaidrot, kāpēc cietušajam kḷuvis slikti un kāpēc ir nepieciešama NMPD darbinieku palīdzība. Jāsecina, ka no analizētās neatliekamās medicīniskās palīdzības izsaukumu elektroniskās dokumentācijas mazāk nekā puse pacientu miruši izsaukuma adresē, bet lielākā daḷa nogādāti ārstniecỉbas iestādē.

\section{LITERATŪRA}

1. Klīniskā anesteziolog̣ija un intensīvā terapija (2017) I. Vanaga, A. Sondores red. Rīga: Medicīnas apgāds. 


\title{
HALLUX VALGUS PROFILAKSE UN POSTOPERATĪVĀ APRŪPE
}

\author{
Eva Briede ${ }^{1}$, Santa Miḳele $e^{1,2}$ \\ 1 Latvijas Universitātes Rīgas 1. medicīnas koledža, Rīga, Latvija \\ 2 SIA "Rīgas 2. slimnīca", Rīga, Latvija
}

Ievads. ASV Nacionālā veselības statistikas centra veiktajā veselības aptaujā tika noskaidrots, ka Hallux valgus skāris ap 1\% pieaugušo Amerikas Savienotajās Valstīs. Saslimstība palielinās proporcionāli vecumam - no $3 \%$ cilvēkiem vecumā no 15 lìdz 30 gadiem, līdz 9\% personām vecumā no 31 līdz 60 gadiem, lìdz 16\% cilvēkiem, kas vecāki par 60 gadiem. Sievietes ar šo problēmu saskaras divas līdz četras reizes biežāk nekā vīrieši. (Epidemiology, 2019).

Hallux valgus deformāciju agrīnā stadijā iespējams izārstēt ar konservatīvām ārstēšanas metodēm. Slimībai progresējot, nepieciešama kirurğiska iejaukšanās, kas 95-99\% gadījumu uzlabo pacienta turpmāko ikdienas dzìves kvalitāti. Ir iespējams apstādināt deformācijas progresēšanu un paātrināt atveselı̆ošanos pēc ķirurgiskas iejaukšanās. (Kas ir jāzina par Hallux valgus vai greizo ìkšķi, 2013).

Darba mērḳis. Noskaidrot, kāda ir Hallux valgus profilakse un postoperatīvā aprūpe.

Materiāli un metodes. Darbā izmantota kvalitatīva pētījuma metode - daḹeji strukturēta intervija. Intervijas jautājumus izstrādājusi autore, pamatojoties uz teorētisko un personīgo pieredzi. Jautājumi strukturēti divos virzienos - par HV profilaksi un postoperatīvās aprūpes specifiku. Intervēti 27 respondenti - medicīnas māsas no 29 līdz 64 gadiem ar profesionālo vidējo medicinnisko, 1. līmeņa profesionālo augstāko izglìtību, bakalaura vai maǵistra grādu Māszinībās, darba pieredzi no 6 līdz 45 gadiem. Pètijums tika veikts laika posmā no 2020. gada 28. aprị̣a līdz 2020. gada 25. maijam Rīgas X slimnīcā.

Rezultāti. Hallux valgus profilaksei 21 respondents ieteiktu lietot ortopēdiskās pēdiņas, 20 ieteiktu veikt speciālus pēdas vingrojumus, lai samazinātu deformācijas progresēšanu, 19 - nēsāt speciālus silikona ieliktņus, 13 - ievērot atpūtu darbā, 12 - lietot bandāžu, 8 - izmantot 15 minūšu ilgas relaksējošas vanniņas, 4 - regulāri apmeklēt ortopēdu - traumatologu, vecumā no 29 līdz 39 gadiem nēsāt ērtus apavus, bieži tos mainìt, no 40 lìdz 49 gadiem ikdienā valkāt apavus ar platu purngalu un papēdi līdz $5 \mathrm{~cm}$. Pacientam agrīnajā pècoperācijas periodā jānodrošina atsāpināšana, pozicionēšana, novērošana, brūces regulāra pārsiešana, antibakteriāla terapija, aukstuma kompreses, pēdas vingrināšana.

Secinājumi. Ievērojot Hallux valgus profilaksi, iespējams apstādināt deformācijas progresēšanu. Postoperatīvais periods pēc Hallux valgus operācijas ilgst līdz 
vienam gadam. Šajā periodā svarīga ir pacienta novērošana, brūces aprūpes specifika un rehabilitācija.

\section{LITERATŪRA}

1. Epidemiology, (2019) Retrieved from https:/emedicine.medscape.com/article/ 1232902-overview\#a6).

2. Kas ir jāzina par Hallux valgus vai greizo ìkšķi? (2013) Pieejams: http://arstiemlv. blogspot.com/2011/02/kas-ir-jazin-par-hallux-valgus-vai.html). 


\title{
MEDIKAMENTOZĀ APRŪPE TIEŠAJĀ PËCOPERĀCIJAS PERIODĀ PËC CEL̦A LOCĪTAVAS ENDOPROTEZĒŠANAS
}

\author{
Aina Sisojeva1 , Daiga Bērtiṇa1 , Maira Vỉksna ${ }^{1,2}$ \\ 1 Latvijas Universitātes Rīgas 1. medicīnas koledža, Rīga, Latvija \\ 2 SIA "Rīgas 2. slimnīca", Rīga, Latvija
}

Ievads. Pēdējos gados pasaulē, tai skaitā Latvijā, ir palielinājies lielo locìtavu slimību skaits, kas galvenokārt aptver pusmūža cilvēkus, vecākus par 50 gadiem. Viena no ārstēšanas metodēm ir ceḷa locitavas endoprotezēšanas operācija. Pilnvērtīga medikamentozā ārstēšana stacionāra posmā l̦auj novērst pacienta veselības stāvokl̦a pasliktināšanos, kā arī nevēlamās blakusparādības. Galvenais medikamentozās aprūpes princips ir savlaicīga tādu komplikāciju novēršana kā infekcija, šḳidruma zudums (dehidratācija), akūtas sāpes, asiņošana un trombembolijas risks. Ievērojot medikamentozās aprūpes principus, tiek samazināta pacientu darba nespēja un dzìves kvalitāti ietekmējošais veselības stāvoklis (Palčeja, 2017).

Darba mērḳis. Izpētìt medikamentozo aprūpi tiešajā pēcoperācijas periodā pēc cel̦a locitavas endoprotēzes.

Materiāli un metodes. Darbā izmantota pētījuma metode - medicīnisko dokumentu analīze. Pētijumā tika apkopota informācija par medikamentozo aprūpi, izmantojot 408 pacientu slimību vēstures laika posmā no 2020. gada februāra līdz 2020. gada maijam.

Rezultāti. Divpadsmit mēnešu intervālā veiktas 408 ceḷa locìtavas endoprotēzēšanas, no tām vidēji mēnesī 16 labā ceḷa locitavas un 17 kreisā ceḷa locìtavas endoprotezēšanas. Vidējais vecums pacientiem, kam veic cel̦a locitavas endoprotezēšanu, ir 69,8 gadi. Pēcoperācijas periodā antibakteriālajā terapijā tiek lietots Cefazolinum, lai izvairītos no infekcijas riska. Šķidruma zudums tiek mazināts, pielietojot infūzijas/transfūzijas terapiju. Atsāpināšanai no narkotiskajiem pretsāpju līdzeklịem plaši tiek pielietots Fentanyl 0,05\%, kas tiek ievadìts vēnā caur perfuzoru, muskulāri - Trimeperidine, kas ir biežāk pielietotais medikaments tiešajā pēcoperācijas periodā. Antitrombolītiskajā terapijā biežāk pielietotais medikaments ir mazmolekulārais heparīns - Zibor (Bemiparinum natricum) $3500 \mathrm{DV}$.

Secinājumi. Pētijuma rezultāti norāda, ka praksē visplašāk izmantotais medikamentozās aprūpes princips tiešajā pēcoperācijas periodā ir savlaicīga komplikāciju novēršana - infekcijas, škidruma zudumu (dehidratācija), akūtu sāpju, asinošanas un trombembolijas riski.

\section{LITERATŪRA}

1. Palčeja E. (2017) Pacientu drošības un veselības aprūpes kvalitātes nodrošināšana. Rīga: Rīgas Stradiņa universitāte. 


\title{
LIPIDOGRAMMAS RĀDĪTĀJI KARDIOVASKULĀRIEM PACIENTIEM AR TRAUKSMI, STRESU UN DEPRESIJU
}

\author{
Paula Rosleviča ${ }^{1}$, Renārs Erts ${ }^{1,2}$, Evija Levenšteina ${ }^{1,3}$ \\ ${ }^{1}$ Latvijas Universitāte, Rīgas Medicīnas koledža, Rīga, Latvija \\ ${ }^{2}$ Latvijas Universitāte, Medicinas fakultāte, Rīga, Latvija \\ ${ }^{3}$ Rīgas Austrumu klīniskā universitātes slimnīca, Rīga, Latvija
}

Ievads. Gadsimtiem ilgi tiek domāts par prāta un ķermeņa mijiedarbību. Arvien plašāk tiek pierādīta psiholog̣isko traucējumu ietekme kardiovaskulāro slimību (KVS) attīstībā. Depresija veicina aterosklerozes veidošanos (Riba et al., 2011), paaugstina jaunu KVS notikumu risku (Rutledge et al., 2006) un, lai gan pierādijumi nav tik spēcīgi, arī trauksme un stress var palielināt KVS risku, līdzīgi kā depresija (Chaddha et al., 2016). Lipīdu vielmainas traucējumi ir plaši pètìti un sen ir pierādīta to loma KVS attīstībā.

Darba mērḳis. Izpētīt un noteikt iespējamās atškirīibas lipidogrammas rādītājos kardiovaskulāriem pacientiem un to saistību ar trauksmi, stresu un depresiju.

Materiāli un metodes. Tika veikts šķērsgriezuma pètijums, piedaloties 879 pacientiem ar dažādām kardiovaskulārām slimībām, vecumā no 18 līdz 80 gadiem. Pētījums norisinājās no 2018. gada 1. janvāra līdz 2020. gada 1. janvārim. Visi pacienti aizpildīja uztvertā stresa anketu (The Perceived Stress Scale (PSS-10)), pacienta veselïbas aptauju (Patient Health Questionnaire-9 (PHQ-9)) un hospitālo trauksmes un depresijas skalu (Hospital Anxiety and Depression Scale (HADS-A)). Visiem pacientiem asins analīzēs tika noteikts triglicerīdu (TG) un kopējā holesterīna $(\mathrm{KH})$ līmenis; $p$ vērtība mazāka par 0,05 tika uzskatìta par statistiski nozīmīgu pielietotajos statistiskos testos.

Rezultāti. Pētijumā piedalijīa $368(41,9 \%)$ sievietes. Pacientu mediānais vecums bija 66 gadi [IQR: 59-73]. 360 respondentiem (40,9\%) tika konstatēta viegla, vidēji smaga vai smaga depresija ( $\mathrm{PHQ}>6$ ) ar mediāno $\mathrm{KH}$ līmeni 4,59 mmol/1 [IQR: 3,81-5,38], salīdzinot ar tiem, kuriem depresijas nav 4,64 mmol/l [IQR: $3,83-5,52](p=0,47)$. TG mediānais līmenis šajās grupās atškīinās statistiski tica$\mathrm{mi}(p=0,01)$, attiecīgi mediāna ir $1,54 \mathrm{mmol} / 1$ [IQR: $1,17-2,17$ ] un $1,40 \mathrm{mmol} / 1$ [IQR: 1,07-1,93]. Subklīniska trauksme konstatēta 91 respondentiem (10,4\%), nozīmīga trauksme 72 respondentiem $(8,2 \%)$. Statistiski ticamas atšķirìbas $\mathrm{KH}$ vidējam lïmenim nevēro $(p=0,43)$, bet, salīdzinot TG vidējo lïmeni respondentiem bez trauksmes, tas mediāni ir 1,45 mmol/l [IQR: 1,08-1,97], ar subklīnisku 1,67 mmol/l [IQR: 1,20-2,20] un attiecigi ar klinisku trauksmi $1,89 \mathrm{mmol} / \mathrm{l}$ $[1,34-2,10](p=0,034)$. Vidējs stress vērojams $466(53,0 \%)$ un augsts $34(3,9 \%)$ 
respondentiem, bez statistiski ticamas atšķirības KH un TG vidējos rādītājos (attiecīgi $p=0,97$ un $p=0,59$ ).

Secinājumi. Vispārliecinošāk iezīmējas paaugstināts triglicerīdu līmenis pacientiem ar depresiju un trauksmi. Ir vērts turpināt pētījumus ar padziḷinātāku lipidogrammas analīzi, veltot lielāku uzmanību triglicerīdu izmaiṇām. Ir pamats domāt, ka, veicinot pacientu mentālo veselību, rodas pozitīvs iespaids uz lipidogrammas rādītājiem, tādējādi tiek uzlabota arī kardiovaskulārā veselība.

\section{LITERATŪRA}

1. Riba M, Wulsin L, Rubenfire M. Psychiatry and Heart Disease: The Mind, Brain, and Heart. Hoboken, NJ: Wiley-Blackwell; 2011.

2. Rutledge T, Reis VA, Linke SE, Greenberg GH, Mills PJ. Depression in heart failure: a meta-analytic review of prevalence, intervention effects, and associations with clinical outcomes. J Am Coll Cardiol. 2006; 48:1527-1537.

3. Chaddha A, Robinson EA, Kline-Rogers E, Alexandris-Souphis T, Rubenfire M. Mental Health and Cardiovascular Disease. Am J Med. 2016 Nov; 129(11):1145-1148. 


\title{
KOGNITĪVO TRAUCĒJUMU IZVĒRTËJUMS PACIENTIEM AR KARDIOVASKULĀRĀM SLIMĪBĀM
}

\author{
Ksenija Murāne ${ }^{1}$, Renārs Erts $^{1,2}$, Sandra Seimane ${ }^{1,3}$ \\ 1 Latvijas Universitātes Rīgas Medicīnas koledža, Rīga, Latvija \\ 2 Latvijas Universitāte, Medicīnas fakultāte, Rīga, Latvija \\ 3 Rīgas Austrumu klīniskā universitātes slimnīca, Rīga, Latvija
}

Ievads. Tradicionālie kardiovaskulāro slimību riska faktori - aptaukošanās, smēķēšana, augsts asinsspiediens un augsts holesterīns - ir riska faktori arī demencei (Papakostas et al., 2004). Zinātnieki joprojām pēta demences iemeslus, bet izmainītām, aterosklerotiskām artērijām ir patogenētiski svarīga nozīme gan sirds slimỉbu, gan kognitīvu traucējumu gadījumos. Kognitīvo traucējumu esamība var traucēt kardiovaskulāro pacientu slimību vadī̌̌anu, mazināt pacientu līdzestību un dzìvesveida pārmaiṇu ieviešanu (Eggermont et al., 2012).

Darba mērḳis. Novērtēt kognitīvos traucējumus pacientiem ar kardiovaskulārām slimībām.

Metodes. Laika posmā no 2018. gada janvāra līdz 2020. gada janvārim tika veikts šķērsgriezuma pētījums, iekḷaujot 950 pacientus, vecumā no 18 lìdz 80 gadiem ar vairākām kardiovaskulārām slimībām. Pacienti tika sadalīti 2 grupās: pacienti ar koronāru sirds slimību un pacienti ar aritmiju (priekškambaru mirdzēšana un plandīšanās). Visiem pacientiem tika skrīnētas kognitīvās funkcijas, lietojot Kognitīvo funkciju Monreālas izvērtēšanas skalu (MoCA - Montreal Cognitive Assessment) (Nasreddine et al., 2005), ar robežvērtību $\geq 26$, kas liecina par normālu kognitīvo funkciju. Pacienti ar iepriekš diagnosticētu demenci netika iekḷauti pētījumā. Datu apstrādei izmantota SPSS-23 programma. $P$ vērtība mazāka par 0,05 tika uzskatìta par statistiski ticamu lietotajos statistiskajos testos.

Rezultāti. Pētījumā piedalījās 549 ( 57,8\%) vīrieši, 551 (58,0\%) latvieši un 365 $(38,4 \%)$ krievu tautỉbas. Pacientu mediānais vecums bija 67 gadi [IQR: 59-73]. Pacientu mediānais MoCA rādītājs bija 25 [IQR: 23-27]. Tikai 396 (41,7\%) pacientiem netika konstatēti kognitīvi traucējumi, viegli kognitīvi traucējumi tika atrasti $483(50,8) \%$ pacientiem, 71 (7,5\%) pacientiem - vidèji smagi vai smagi kognitīvo funkciju traucējumi. Netika novērota statistiski ticama atškirība kognitīvos rādītājos starp kardiovaskulārām diagnožu grupām $(p=0,59)$.

Secinājumi. Ievērojamam skaitam pacientu ar KVS ir kognitīvo funkciju traucējumi, kas ir jāṇem vērā, piemēram, sniedzot rekomendācijas dzīvesveida pārmaiṇu ieviešanai un ārstēšanas stratēgijas izvēlē īsākā, koncentrētākā veidā vai, iespējams, šo informāciju pat nododot un izskaidrojot tuviniekiem. 


\section{LITERATŪRA}

1. Papakostas G.I., Ongur D., Iosifescu D.V., Mischoulon D., Fava M. Cholesterol in mood and anxiety disorders: review of the literature and new hypotheses. Eur Neuropsychopharmacol. 2004; 14(2):135-42.

2. Eggermont LHP, de Boer K, Muller M, et al Cardiac disease and cognitive impairment: a systematic review Heart 2012; 98:1334-1340.

3. Nasreddine, Z.S., Phillips, N.A., Bédirian, V., Charbonneau, S., Whitehead, V., Collin, I., Cummings, J.L. and Chertkow, H. (2005), The Montreal Cognitive Assessment, MoCA: A Brief Screening Tool For Mild Cognitive Impairment. Journal of the American Geriatrics Society, 53:695-699. https://doi.org/10.1111/j.1532-5415.2005.53221.x 


\title{
AUTONOMIJAS PRINCIPS ĶIRURG̣ISKĀS APRŪPES MĀSAS PRAKSĒ
}

\author{
Linda Alondere, Inga Veidemane
}

Latvijas Universitātes Rīgas Medicīnas koledža, Rīga, Latvija

Ievads. Medicīnas zinātnes un tehnolog̣iju izaugsme radījusi ètiskas problēmas un mainïjusi pasauli. Ieskats cilvēka genomā, gēnu mikroshēmu un nanotehnolog̣ijas attīstība mainīja medicīnas laikmetu (Thomas, 2007). Zināšanu apguve un medicīniskās ētikas pamatprincipu ievērošana ir vienlīdz svarīga (Thomas, 2007; Raza et al., 2016). Autonomija ir viens no medicīnas ètikas pamatprincipiem, un pētnieki uzskata, ka māsu profesionālās autonomijas līmenis ir process, kas izstrādāts, mijiedarbojoties ar pacientiem un rūpējoties par tiem. Japāṇu zinātnieki noskaidrojuši, ka māsām, kas strādā operāciju zālēs vai intensīvās terapijas nodalāas, ir augstāka profesionālā autonomija nekā citās nodaḷās. ASV pētījumā norādīts, ka māsām, kas strādā kirurğijas, psihiatriskajās un dzemdību nodạ̣ās, ir augstāka profesionālā autonomija, salīdzinot ar intensīvās terapijas nodaḷu māsām. Autonomija ir sarežğìts, daudzdimensionāls jēdziens un profesionalitātes pamats (Setoodegan et al., 2019).

Darba mērḳis. Noskaidrot, kā autonomijas princips tiek īstenots ķirurğiskās aprūpes māsas praksē.

Materiāli un metodes. Rezultātu apkopošanai izmantota bibliometrijas metode. Atlasìtas pilna teksta bezmaksas publikācijas datu bāzē "PubMed" (2015-2020), izmantojot atslēgvārdus: māsu autonomija, autonomijas princips ķirurğijas aprūpes māsas praksē, tās jēdzieni, autonomijas principu elementi, informācijas un lēmumu pieņemšana, privātums, konfidencialitāte. Kopā tika analizētas deviņas publikācijas, to rezultātus apkopojot laika periodā no 2020. gada 8. septembra līdz 2021. gada 5. janvārim.

Rezultāti. Anglijā veikts aprakstošs fenomenologisks pētijums "Registered nurses' perceptions and experiences of autonomy: a descriptive phenomenological study". Pētnieki norāda, ka praktizējošo māsu izlasē trūkst vienprātības par autonomijas jēdzienu. Tiek norādīts, ka nav noteiktas autonomijas definīcijas, un konstatēta autonomijas interpretācijas dažādība (Oshodi et al., 2019). Savukārt pētījumā "Patient Participation in Decision Making During Nursing Care in Greece A Comparative Study" secināts, ka pacientu līdzdalība, lai arī mērena, bija acīmredzama slimnīcas apstākḷos. Paternalisms lēmumu pieņemšanas procesā bija dominējošā tendence, turpretim pušu savstarpējā mijiedarbība atzîta par priekšnoteikumu aprūpes plānošanai (Kolovos et al., 2015). Spānijā veiktā pētijumā "Impact of Nurse-Patient Relationship on Quality of Care and Patient Autonomy in Decision-Making", analizējot māsu dokumentāciju, secināts, ka trūkst pacienta 
autonomijas lēmumu pieņemšanā par viņu aprūpi un ka māsas dod priekšroku pakḷāìigam pacientam, kurš uzņemas aprūpi bez diskusijām, respektējot māsas darbu (Molina-Mula, Gallo-Estrada, 2020). ASV pētījumā "Better nurse autonomy decreases the odds of 30-day mortality and failure to rescue" iegūti rezultāti, ka māsas, kas praktizē mazās slimnīcās, kur neveic izglìtojošo darbu, ziņoja par visaugstāko, savukārt māsas vidējās un nelielās slimnīcās, kur veic mācības, ziṇoja par viszemāko autonomijas līmeni. Secināts, ka slimnīcas ar zemāku māsu autonomijas līmeni ķirurğiskajiem pacientiem rada paaugstinātu mirstỉbas risku (Rao et al., 2017).

Secinājumi. Pēc mērķtiecīgām literatūras studijām secinām, ka autonomija ir nozīmīga un tā ir būtiska māsas profesijas īpašìba. Māsu un pacientu attiecības ietekmē aprūpes kvalitāti un pacienta autonomiju lēmumu pieņemšanā. Māsām un citiem veselïbas aprūpes speciālistiem jāsaprot autonomijas nozīme un faktori, kas veicina vai samazina autonomiju aprūpē.

\section{LITERATŪRA}

1. Kolovos P., Kaitelidou D., Lemonidou C., Sachlas A. \& Sourtzi P. (2015). Patient Participation in Decision Making During Nursing Care in Greece-A Comparative Study. Nurs. Forum. 50:147-157. PMID: 24620895/

2. Molina-Mula J.\&Gallo-Estrada J. (2020). Impact of Nurse-Patient Relationship on Quality of Care and Patient Autonomy in Decision-Making. Int. J. Environ. Res. Public Health 17, 835. PMCID: PMC7036952.

3. Oshodi TO., Bruneau B., Crockett R., Kinchington F., Nayar S. \& West E. (2019). Registered nurses' perceptions and experiences of autonomy: a descriptive phenomenological study. BMC Nurs. 18: 51. PMCID: PMC6823973.

4. Rao AD, Kumar A, McHugh M. (2017) Better nurse autonomy decreases the odds of 30-day mortality and failure to rescue. J Nurs Scholarsh.; 49:73-79.

5. Raza M., Dharamshi HA., Ahsan SZ., Naqvi Z., Naqvi T., Ali AAM. \& Abbas JM. (2016). The Future of Ethics in Medicine. Iran Red Crescent Med J. Jun; 18(6). PMCID: PMC5003096

6. Setoodegan E., Gholamzadeh S., Rakhshan M. \& Peiravie H. (2019). Nurses' lived experiences of professional autonomy in Iran. Int J Nurs Sci. Jul 10; 6(3): 315-321. PMCID: PMC6722471.

7. Thomas NG. (2007). Ethics in the Age of Medical Device Technologies. American Medical Association Journal of Ethics February Volume 9, Number 2: 83-85. 


\title{
MĀSU UN MEDICĪNAS ASISTENTU IZPRATNE PAR ERGONOMIKU, TĀS PAMATPRINCIPIEM UN TO PIELIETOJUMU DARBA VIDĒ
}

\author{
Samanta Bērziṇa, Jeḷena Kuzṇecova \\ Latvijas Universitātes Rīgas Medicīnas koledža, Rīga, Latvija
}

Ievads. Zināms, ka cilvēka fiziskajai un psihosociālai spējai nepiemērotas slodzes darbs var potenciāli radīt veselības traucējumus, kas sabiedrībā zināmi kā arodslimības un ar darbu saistitas slimības (Latvijas Arodslimību Ārstu biedrība, 2019). Savukārt, lai aizkavētu arodslimību attīstību, liela nozīme ir ergonomikas pamatprincipu ievērošanai un pielietošanai. Veselības aprūpes nozarē pieaug to medicīnas darbinieku skaits, kuriem tiek diagnosticēta arodslimỉba, piemēram, 2000. gada sākumā 6-7\% no arodslimniekiem bija medicinas darbinieki, savukārt 2014. gadā jau 15\% arodslimnieku bija veselības aprūpes nozarē strādājošie (Pastore, Skrebele, 2016). Ikdienā fiziski smagu darbu veic gan māsas, gan medicīnas asistenti, kas ilgtermiņā var radīt nopietnus veselības traucējumus, rezultātā ietekmējot gan veicamā darba kvalitāti, gan paša darbinieka labsajūtu un labklājību.

Darba mērḳis. Noskaidrot māsu un medicīnas asistentu izpratni par ergonomiku, tās pamatprincipiem un to pielietošanu darba vidē.

Materiāli un metodes. Pētijumā izmantota kvantitatīvā datu vākšanas metode - anketēšana. Anketa satur 21 jautājumu. Pētījums tika veikts laika posmā no 2020. gada 12. februāra līdz 1. aprīlim, un tajā piedalijās 134 respondenti, no kuriem 132 sievietes un 2 vīrieši vecuma diapazonā no 20 līdz 70 gadiem, vidējais vecums 39,6 gadi.

Rezultāti. Pētījumā iegūtie rezultāti pierāda, ka kopumā māsām un medicīnas asistentiem ir izpratne par tādiem tematiem kā ergonomikas definīcija, ergonomikas pielietošana pacientu pārvietošanas procesā, spēka, slodzes un kustību samazināšanas principi un arodslimību rašanos ietekmējošie faktori darba vidē, tomēr salīdzinoši mazāka izpratne ir par neitrālu darba pozīciju un spēju to atpazìt un pielietot.

Lielākā daļa respondentu (83\%) izprot optimālo metodi smagu priekšmetu pārvietošanā, savukārt 38\% respondentu atzina, ka nepietiekams darbs komandā pacientu pārvietošanas procesā ir nozīmīgākais ergonomiskais riska faktors darba vidē. Aptuveni piektā daļa respondentu (22\%) atzina, ka darba vidē nav iespējams pielietot kādu no piedāvātajiem ergonomikas principiem, tikai 24\% respondentu apstiprina, ka darbā bieži lieto neitrālu pozīciju. Gandrīz trešdaļa respondentu (27\%) atzīmēja, ka savā darba vidē saskaras ar piespiedu pozīciju kā riska faktoru un 13\% respondentu atzīmēja, ka visbiežāk darbā saskaras ar pārtraukumu trūkumu. 
Secinājumi. Lai arī kopumā respondentu izpratne par ergonomikas tematiem ir optimāla, mazai daļai respondentu ir izpratne par principiem, kas attiecas uz neitrālas pozīcijas atpazišanu un pielietošanu. Jāatzīmē, ka lielākā daļa respondentu izprot, ka pacientu celšanā un pārvietošanā būtiska loma ir darbinieku izglìtošanai par drošām pārvietošanas tehnikām un arī komandas darbam pārvietošanas procesā, tomēr liela daļa respondentu savā darba vidē sastopas ar dažādiem ar ergonomiku saistīiem riska faktoriem, piemēram, piespiedu pozīiju, statisku pozīciju un pārtraukumu trūkumu darbā.

\section{LITERATŪRA}

1. Latvijas Arodslimību ārstu biedrība. Kas ir arodslimības/ar darbu saistìtās slimības un arodslimības [tiešsaiste]. [skatits 16.03.2019.]. Pieejams: http://www.arodslimibas.lv/ index.php? $\operatorname{module}=\bmod 91$

2. Pastore K., Skrebele G. (2016). Cik smaga profesionālā nasta? Mediķu arodslimības [tiešsaiste]. [skatitts 20.12.2019.]. Pieejams: https://www.doctus.lv/2016/5/ciksmaga-profesionala-nasta-mediku-arodslimibas 


\title{
ĀRSTA PALĪGU MOTIVĀCIJA DARBAM NEATLIEKAMĀS MEDICĪNISKĀS PALĪDZĪBAS DIENESTĀ
}

\author{
Montija Bičevska, Sarmīte Villere \\ Latvijas Universitātes Rīgas Medicīnas koledža, Rīga, Latvija
}

Ievads. Ārsta palīgs ir l,oti atbildīga un sarežğita profesija, kam nepieciešamas labas teorētiskās un praktiskās zināšanas, kas jāspēj ātri un precīzi pielietot. Apgūt šo profesiju cilvēki izvēlas vairāku iemeslu dēḷ: ārsta palīgs ir pieprasīta profesija darba tirgū, kā arī tā dod iespēju ikdienā palīdzēt nelaimē cietušajiem un glābt dzīvības. Praksē var novērot, ka darbinieku motivācija pazeminās zemā atalgojuma un nesakārtotās veselības aprūpes sistēmas dēl, darbinieki “izdeg”. Neatliekamās medicīniskās palīdzības dienesta direktore Liene Cipule atzina, ka patlaban dienestā trūkst 587 mediḳi, bet vēl 200 personu tuvākajā laikā dosies izdienas pensijā'1 2018. gadā Latvijā bija reǵistrēti 2295 praktizējoši ārsta palīgi. ${ }^{2}$

Pētījuma mērḳis. Noskaidrot ārsta palīgu motivāciju darbam Neatliekamās medicīniskās palīdzības dienestā.

Materiāli un metodes. Pētījumā izmantota kvalitatīvā datu vākšanas metode-intervija, kuras jautājumus izstrādāja pētījuma autores. N̦emot vērā Corona vīrusa (Covid-19) izraisīto pandēmiju, vairākas intervijas notika arī vietnē ZOOM. Respondentiem tika uzdoti 9 atvērtie jautājumi.

Pētījuma dalībnieki. Pētījuma periods 2020. gada 1. aprīlis - 30. maijs, kad tika intervēti 12 NMPD strādājoši ārsta palīgi, 17\% vīrieši un $83 \%$ sievietes, vecumā no $26 \mathrm{lī} \mathrm{dz} 64$ gadiem, vidējais respondentu vecums 38 gadi. Pirms pētījuma veikšanas tika saṇemta Ētikas komitejas atḷauja Nr. 43, un respondenta piekrišana dalïbai pētījumā.

Rezultāti. Sekojot vecāku vai radinieku ieteikumiem, 70\% respondentu atzina, ka izvēlējušies profesiju, piemēram, izcel̦ot aizraušanos ar vēlmi palīdzēt. "N̦ēmu piemēru no vecākiem, redzēju, ar kādu aizrautību un mìlestību viņi palìdz cilvēkiem." (Respondents K).

Savukārt 30\% respondentu atzina, ka izvēlējušies šo profesiju lielā pieprasījuma pēc darbiniekiem dēḷ. Intervijas jautājums "Kā jūs vērtējat ārsta palīga darba apstākḷus Latvijā?” 80\% respondentu izsauca negatīvas emocijas, jo darbinieki jūtas nenovērtēti.

“Atalgojumam, manuprāt, būtu jābūt tādam, lai nav jāstrādā vairākās darbavietās gimenes uzturēšanai, izsakot skaiț̣los - apmēram 2000-2500 eiro. Savādāk jaunus darbiniekus neiegūsim." (Respondents L). 
Ārsta palīgi atzīst, ka ir nepieciešami uzlabojumi veselības aprūpē: "Finansējuma trūkums padara veselības sistēmu nepieejamu. Garas rindas uz ambulatorajiem pakalpojumiem. Rezultātā liela daḷa iedzīvotāju slimo ar hroniskām kaitēm." (Respondents D).

\section{Secinājumi}

1. NMPD darbinieku motivāciju pazemina tādi faktori kā vāji organizēta veselības aprūpes sistēma, zemais atalgojuma apmērs, sajūta, ka darbinieki ir nenovērtēti un dotajā brīiñ motivācija ir vērtējam kā zema.

2. NMPD darbinieku motivāciju veicina tādi faktori kā vēlme palīdzēt, helper's high fenomens, gimenes atbalsts, darbs ar pacientiem ir vinu sirdslieta.

\section{LITERATŪRA}

1. LETA (2019). Mediku trūkuma dēl NMPD varētu pakāpeniski pāriet uz divu personu brigādēm. [Tiešsaiste] Pieejams: https://jauns.lv/raksts/par-veselibu/346496-medikutrukuma-del-nmpd-varetu-pakapeniski-pariet-uz-divu-personu-brigadem

2. Slimïbu profilakses un kontroles centrs (2019). Statistikas dati par ärstniecïbas personu skaitu. [MS Word] Pieejams: https://www.spkc.gov.lv/sites/spkc/files/data_content/ cilvekresursi_2018_120620191.doc 


\section{DARBA VIDES RISKA FAKTORI SOCIĀLĀS APRŪPES UN SOCIĀLĀS REHABILITĀCIJAS INSTITŪCIJĀ}

\section{Inga Rūža, Līga Priede}

Latvijas Universitātes P. Stradiṇa medicīnas koledža, Jūrmala, Latvija

Ievads. Sociālais aprūpētājs, savā darbā ir pakḷauts psihosociāliem un organizatoriskiem faktoriem, tādiem kā stress, izdegšanas sindroms, emocionālā un fiziskā vardarbība, fizikāliem, biologiiskiem, ḳīmiskiem un ergonomiskiem faktoriem.

Pēc Starptautiskās darba organizācijas vērtējuma Kaḷ̦is, Roja un Kaļ̣̣is (2015), psihosociālie un organizatoriskie riska faktori raksturo mijiedarbību starp darba saturu un apstākḷiem.

Aktuāla problēma ir darbinieku fiziskā sagatavotība un emocionālā stabilitāte darbā un ārpus darba, jo sevišḳi šajā neparedzami grūtā Covid-19 pandēmijas laikā, kad ir ieviesti dažādi ierobežojumi un vadlīnijas.

Epidemiologíiskās drošības likums (2020), nosaka personas pienākumu nepakḷaut citas personas inficēšanās riskam. Tāpēc sociālās aprūpes un sociālās rehabilitācijas nozarei, rūpējoties par savu tēlu, jārada ne tikai komfortabli un droši darba apstākḷi, bet arī jāprot tos pieskaņot katra nodarbinātā fiziskām un garīgām spējām, sociālām iespējām, veicinot darbinieku līdzdalību darbu plānošanā un efektīvu darba apstākḷu nodrošināšanā.

Pētijuma mērḳis: izpētìt darba vides riska faktorus institūcijā sociālo darba speciālistu un aprūpes komandas darbības procesā.

Materiāli un metodes. Darba procesā tika analizēta literatūra, informācijas avoti par darba vides riska faktoriem, sociālās aprūpes un sociālās rehabilitācijas institūcijās, tika analizēti normatīvie akti. Tika izstrādāts pētījuma instruments par darba vides riska faktoriem. Aptaujas anketā iekḷautas sadaḷas: psihosociālie un organizatoriski faktori; fizikālie faktori; biologiskie faktori; kīmiskie faktori; ergonomiskie faktori un Covid-19 ietekme sociālā aprūpètāja darbā. Pētijuma bāze VSAC "Latgale" filiāle "Krastiņi", respondenti šìs filiāles sociālās aprūpes un sociālās rehabilitācijas komanda. Tika veikta respondentu anketēšana, anketu izstrādāja kvalifikācijas darba autore, veikta pētijuma analīze un izdarīti secinājumi. Pētijums tika veikts 2021. gada februārī-martā.

\section{Rezultāti}

Aptaujā 100\% ( $n=34)$ visi respondenti atzīmējuši, ka ievēro drošìbas pasākumus Covid-19 infekcijas laikā. 70\% $(n=24)$ aptaujāto neietekmē psihosociālie faktori, kā arī 60\% $(n=20)$ aptaujāto atzīmē, ka nav veselības problēmas, kas saistīti ar nelabvēlīgiem ergonomiskiem faktoriem. 


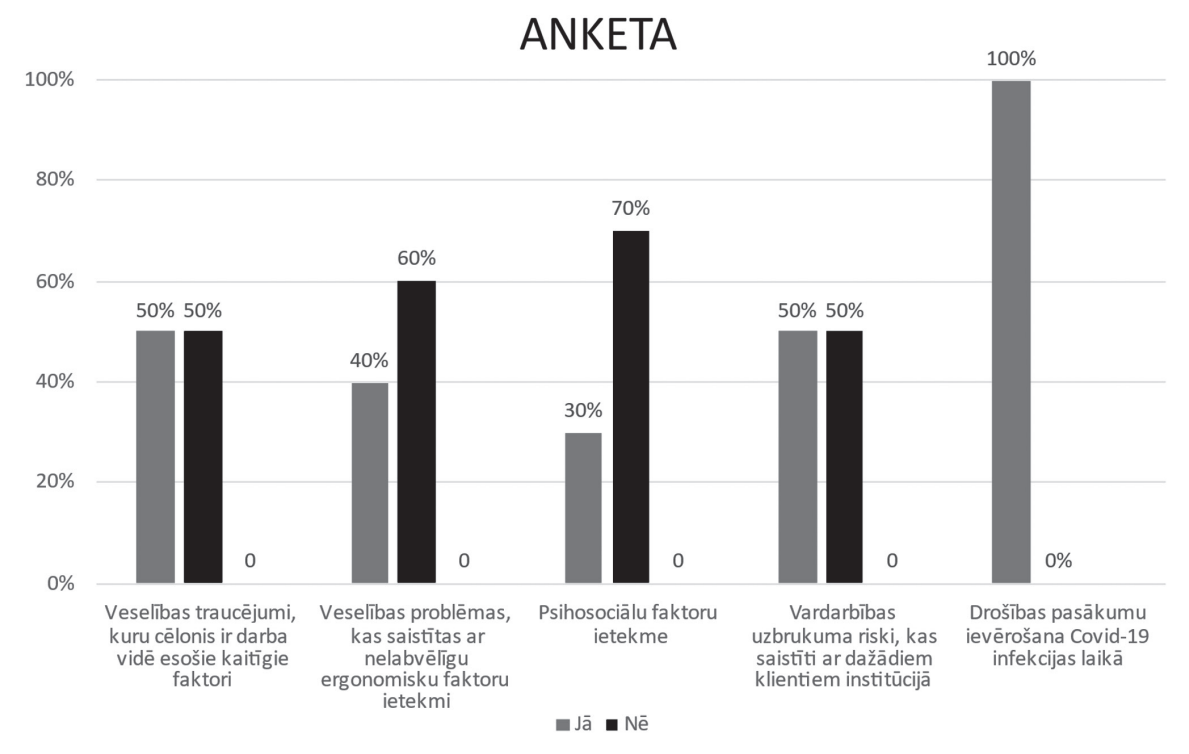

\section{1. att. Darba vides riska faktoru izvērtējums (\%)}

\section{Secinājumi}

- Apkopojot rezultātus, kas saistīti ar ergonomiko faktoru ietekmi darbā ar klientiem, lielākā daḷa respondentu atzīmē, kā ir pasargāti no balsta un kustības aparāta slimībām, jo ir sakārtota darbavieta un uzlabota organizācijas sistēma, kas rada labvēlīgu darba vidi.

- Darba procesu optimizējošie pasākumi un pozitīvie psihosociālie faktori palīdz darbiniekam saglabāt labsajūtu, uzlabo indivīda darba spējas un rada pozitīvu darba mikroklimatu.

- Vardarbības riski, kas saistīti ar klientu uzbrukumiem personālam pastāv, jo klienti ar garīga rakstura traucējumiem dažādās situācijās var reagèt neadekvāti, darbinieks nav pasargāts no šāda veida riska.

- Institūcijā tiek ievērota epidemiologiskās drošības prasību ievērošana, kas saistīta ar Covid-19 vīrusa izplatību.

\section{LITERATŪRA}

1. Kalı̧̦is, V., Roja, Ž., un Kaḷkis, H. 2015. Arodveselība un riski darbā. Medicīnas apgāds, 510. lpp.

2. Epidemiologiskās drošības likums Saeimā pieṇemts 11.12.1997. likums stājas spēkā 13.01.1998. Iegūts no: https://likumi.lv/doc.php?id=52951 [sk. 09.02.2021.].

3. Darba aizsardzības prasības, veselības un sociālās aprūpes iestādēs. 2012. Rìgas Stradiṇa universitātes Darba drošības un vides veselïbas institūts. Iegūts no: 2012. http://stradavesels.lv/Uploads/2014/07/16/110_2012_Brosura_Veselibas_aprupe. pdf[sk.09.02.202. 


\section{KLAUSĪŠANĀS PRASME KĀ KOMUNIKĀCIJU IETEKMĒJOŠS FAKTORS SOCIĀLĀ REHABILITĒTĀJA DARBĀ}

\section{Zane Imūne, Kristīne Vìtoliṇa}

Latvijas Universitātes P. Stradina medicīnas koledža, Jūrmala, Latvija

Ievads. Sociālā rehabilitētāja profesionālā darbība nevar pastāvēt bez saziņas procesa. Lai strādātu ar klientiem, ir nepieciešama visaptveroša komunikācijas prasme. Zdebska (2011) apraksta, ka sociālā rehabilitētāja darba efektivitāte ir atkarīga ne tikai no informācijas sniegšanas, bet arī no klausišsanās, kas sociālās darbības jomā ir ḷoti svarīgs komunikācijas elements. Omārova (2009) secina, ka prasme klausîties pieder pie vissvarīgākajām cilvēka komunikatīvajām iemaņām. Ar prasmīgu klausīšanos radām par sevi labu iespaidu, labāk izzinām klienta vajadzības un intereses, kā arī saņemam daudz jaunas informācijas. Saikne, kas veidojas izmantojot aktīvu klausī̌sanos, ir viens no galvenajiem sociālā rehabilitētāja veiksmīgas sadarbības ar klientu resursiem, kā arī klienta sociālo problēmu risināšanas pamatā.

Darba mērḳis. Noskaidrot sociālo rehabilitētāju viedokli par klausīšanās prasmes nozīmi darbā ar klientiem.

Materiāli un metodes. Izvirzìtā mērḳa sasniegšanai autore analizēja literatūras un informācijas avotus. Datu ieguvei tika izmantota kvalitatīvā pētniecības metode, kas ietvēra pētijuma instrumenta - intervijas izveidi. Pētijuma ietvaros, laika posmā no 22.02.2021. lìdz 14.03.2021., tika intervēti 5 respondenti - sociālie rehabilitētāji.

Rezultāti. Norādot sarunu, kā galveno sociālā rehabilitētāja instrumentu darbā ar klientiem, visi 5 respondenti uzsvēra klausīšanās prasmju būtisko un neaizstājamo lomu veiksmīgā sadarbībā. Visi 5 respondenti atzīmēja, ka pārliecināties par klienta sacìtā pareizu izpratni palīdz pārfrāzēšana, iegūtās informācijas apkopošana, reflektēšana un papildu jautājumu uzdošana. No respondentu sniegtajām atbildēm redzams, ka 2 respondenti norādīja uz klausīšanās prasmes nemitīgu pilnveidošanas nepieciešamību, lai uzlabotu komunikāciju. Visi 5 respondenti norādīja, ka šīs prasmes praksē pielietot nav viegli un jācenšas izvairīties no nepamatotas pārtraukšanas, provokatoriskām piebildēm, tēmas mainǐšanas vai vērtējuma izdarǐšanas. 3 respondenti uzsvēra, ka klausǐšanās prasme pilnveidojas tieši praktiskajā darbībā. 5 respondenti atzīmēja, ka, neuzmanīgi klausoties klientā, nevar izprast klienta vajadzības, līdz ar to nav iespējams atbilstoši reagêêt un sniegt nepieciešamo palīdzību. Paužot viedokli, par rīcību situācijās, kurās klients ir agresīvs, 2 respondenti atzīmēja, ka svarīgi saglabāt mieru, bet 3 respondenti norādīja, ka jārada droša un atbalstoša vide klientam. Visi respondenti akcentēja, ka labākais 
risinājums ir mierīga klienta uzklausīšana, bez moralizēšanas, sava viedokḷa uzspiešanas vai taisnības pierādī̌̌anas.

Secinājumi. Analizējot rezultātus, var secināt, ka sociālā rehabilitētāja darbā klausīšanās prasme ir veiksmīgas sadarbības pamatā starp klientu un profesionāli, jo tiek panākta uzticēšanās, kas rada klientam drošības sajūtu un veicina līdzestību sociālo jautājumu risināšanā. Sociālajam rehabilitētājam ir svarīgi sagatavoties sarunai ar klientu, kas ietver sarunas laika plānošanu, būtiskāko jautājumu akcentēšanu, vides izvēli un konfidencialitātes ievērošanu. Raksturojot klausī̌̌anās prasmes nozīmi darbā ar klientu, sociālie rehabilitētāji to atzina par veiksmīgas sadarbības atslēgu. Efektīvas klausǐšanās ieguvums ir gan saṇemtā informācija, gan klientam izrādītā uzmanība un pozitīvā attieksme, kas sekmē ieklausīšanos profesionāla viedoklī un uzlabo sadarbību.

\section{LITERATŪRA}

1. Omārova, S. 2009. Cilvēks runā ar cilvēku. Rīga: Kamene, 136 lpp.

2. Zdebska, E. Komunikacja w pracy socjalnej. No: Łukasik, J. zesp. red. 2011. Debata edukacyjna. Rocznik nr.4. Krakow: Wydawnictwo Naukowe UP, 104 str. 


\title{
STUDIJU PROCESS KĀ PROFESIONĀLĀS IDENTITĀTES VEICINĀTĀJS SOCIĀLĀ DARBA SPECIĀLISTIEM
}

\author{
Kristīne Vitoliṇa, Ina Vỉksniṇa, Ina Ozola, Līga Priede \\ Latvijas Universitātes P. Stradina medicīnas koledža, Jūrmala, Latvija
}

Ievads. Profesionālā identitāte apliecina indivīda piederību profesijai, un to raksturo prasmju, kompetenču un sasniegumu komplekss. Karjeras izaugsmē būtiska nozīme ir profesionālās identitātes attīstǐšanai, kas aizsākas jau studiju procesā. Tās veidošanās ir katras profesijas pamatvērtība, kas balstās uz profesijas standartu. Profesionālisma pētnieki Crues et al. (2014) profesionālo identitāti definē kā pašpietiekamību un uzskata, ka tā veidojas pakāpeniski, iekḷaujot profesijai raksturīgās īpašības, vērtības un normas. Moors (2007) atzīmē, ka profesionālās identitātes veidošanos ietekmē vairāki faktori - profesionalitāte, profesionālu lēmumu pieņemšana un atbildība par savu rīcību. Reid et al. (2011) atzìmē, ka profesionālās identitātes attīstībā nozīme ir studiju procesam, kurā tiek īstenotas divas funkcijas - zināšanu un prasmju apguve un tādēḷ nepieciešams regulārs studiju procesa novērtējums.

Darba mērķis. Noskaidrot studējošo, absolventu un darba devēju viedokli par studiju procesu un to raksturojošajiem faktoriem profesionālās identitātes veicināšanā.

Materiāli un metodes. Mērķa sasniegšanai, tika analizēti profesionālās literatūras un informācijas avoti, izmantota kvantitatīvā pētniecības metode, kas ietvēra koledžas docētāju izstrādātu un aprobētu pētījuma instrumentu - anketu, izmantošanu studējošajiem, absolventiem un darba devējiem, analizēti un interpretēti iegūtie dati un izdarīti secinājumi. Aptaujas veiktas vairākos posmos, laika periodā no 2014. līdz 2020. gadam. Anketās iekḷauti jautājumi par studiju procesa ietekmējošajiem faktoriem, darba iespējām pēc studiju beigšanas un jauno speciālistu sagatavotību darba tirgum.

Rezultāti. Aptaujās iegūts 355 studējošo viedoklis par studiju kvalitāti, materiāli tehnisko nodrošinājumu, docētāju prasmi, izskaidrot teorētisko materiālu un vērtēšanas kritērijus, sadarbību starp docētāju un studējošo, kā arī literatūras pieejamību. Septiṇu pārskata periodu laikā vidēji 95\% $(n=337)$ studējošie studiju kursu kvalitāti novērtēja kā labu. Savukārt pasniedzēju spēju izskaidrot studiju kursu mērksus un prasības labi novērtēja vidēji $82 \%(n=291)$. Materiāli tehnisko nodrošinājumu kā l̦oti labu novērtēja vidēji 98\% $(n=347)$ studējošie. Analizējot 280 absolventu viedokli, tika iegūti rezultāti par studiju kvalitāti un profesionālajā darbībā nepieciešamo prasmju apguvi, izvēlētās profesijas iespējām darba tirgū un studiju turpināšanu. Novērtējot studiju programmas kvalitāti, vidēji 48\% (n= 
148) absolventi deva vērtējumu teicami. Savukārt kā labu studiju kursu kvalitāti novērtēja vidēji 44\% ( $n=123)$ absolventi. Darba devēju aptauju rezultāti parāda, ka jaunie speciālisti ir motivēti strādāt savā profesijā, par ko liecina vērtējums izcili 60\% $(n=31)$ un vērtējums labi 31\% $(n=16)$ atbilžu gadījumā. Vidēji 59\% $(n=88)$ darba devēju jauno speciālistu teorētiskās zināšanas un praktiskās iemaņas, spēju strādāt komandā un spēju reagèèt novērtē kā izcilas. Negatīvu vērtējumu nebija nevienā respondentu grupā.

Secinājumi. Profesionālās identitātes veidošanai ir svarīgi vairāki komponenti-profesijas filozofija, profesionālās zināšanas, lomas, motivācija, uzvedība un attieksme pret darbu. Profesionālā identitāte ir piederības sajūta konkrētai profesionāḷu grupai, kā arī attieksme, zināšanas un prasmes, kas nepieciešamas darbā ar klientiem un starpprofesionāḷu komandā. Studiju procesa laikā tiek pievērsta uzmanība profesionālo identitāti veidojošajiem komponentiem, un tie tiek aktualizēti, tādējādi veicinot profesionālās piederības attīstību.

\section{LITERATŪRA}

1. Cruess, R. L., Cruess, S. R., Boudreau, J. D., Snell, L., Steinert, Y. 2014. Reframing medical education to support professional identity formation. Acad. Med. 89:1446-1451.

2. Moors, M. 2007. Sociālā darbinieka profesionālās identitātes veidošanās problēmas. Sociālais darbinieks, Nr. 2(23), 10.-13. lpp.

3. Reid, A., Abrandt Dahlgren M., Petocz P., Dahlgren L. O. 2011. From Expert Student to Novice Professional. Springer; Dordrecht, The Netherlands, 137 p. 